\title{
Pursuing Precision: Receptor Tyrosine Kinase Inhibitors for Treatment of Pediatric Solid Tumors
}

\author{
Andrew J. Bellantoni (D) and Lars M. Wagner*(D) \\ Division of Pediatric Hematology/Oncology, Duke University, Durham, NC 27710, USA; \\ andrew.bellantoni@duke.edu \\ * Correspondence: lars.wagner@duke.edu
}

check for updates

Citation: Bellantoni, A.J.; Wagner, L.M. Pursuing Precision: Receptor Tyrosine Kinase Inhibitors for Treatment of Pediatric Solid Tumors. Cancers 2021, 13, 3531. https://doi.org/10.3390/cancers 13143531

Academic Editor: Michele Bernasconi

Received: 10 June 2021

Accepted: 9 July 2021

Published: 14 July 2021

Publisher's Note: MDPI stays neutral with regard to jurisdictional claims in published maps and institutional affiliations.

Copyright: (C) 2021 by the authors. Licensee MDPI, Basel, Switzerland. This article is an open access article distributed under the terms and conditions of the Creative Commons Attribution (CC BY) license (https:/ / creativecommons.org/licenses/by/ $4.0 /)$.
Simple Summary: Children with metastatic or relapsed solid tumors remain in desperate need of better treatment since conventional chemotherapy is often ineffective and can cause long-term complications. Precision oncology offers the possibility of less toxic and more beneficial treatment through the targeting of critical molecular vulnerabilities in tumors. Small molecule inhibitors of receptor tyrosine kinases have shown impressive activity in treating tumors with activating kinase fusions that drive oncogenesis and demonstrate the potential promise of precision oncology. However, in the absence of fusions or activating mutations, the activities of these agents have been more modest and are limited by intrinsic or acquired resistance and the lack of predictive biomarkers. In this manuscript, we track the development of receptor tyrosine kinase inhibitors for treating extracranial pediatric solid tumors and discuss relevant strategies to help optimize the use of these agents.

Abstract: Receptor tyrosine kinases are critical for the growth and proliferation of many different cancers and therefore represent a potential vulnerability that can be therapeutically exploited with small molecule inhibitors. Over forty small molecule inhibitors are currently approved for the treatment of adult solid tumors. Their use has been more limited in pediatric solid tumors, although an increasing number of single-agent and combination studies are now being performed. These agents have been quite successful in certain clinical contexts, such as the treatment of pediatric tumors driven by kinase fusions or activating mutations. By contrast, only modest activity has been observed when inhibitors are used as single agents for solid tumors that do not have genetically defined alterations in the target genes. The absence of predictive biomarkers has limited the wider applicability of these drugs and much work remains to define the appropriate patient population and clinical situation in which receptor tyrosine kinase inhibitors are most beneficial. In this manuscript, we discuss these issues by highlighting past trials and identifying future strategies that may help add precision to the use of these agents for pediatric extracranial solid tumors.

Keywords: pediatric solid tumors; targeted therapies; precision medicine; personalized medicine; receptor tyrosine kinases; tyrosine kinase inhibitors

\section{Introduction}

Current treatment for pediatric solid tumors typically combines chemotherapy with surgery and/or radiotherapy. Chemotherapy regimens used for sarcoma, neuroblastoma, and tumors of the liver or kidney primarily include conventional cytotoxic drugs, often with combinations that are decades old and broadly applied [1-5]. Although many children with solid tumors become long-term survivors, those with metastatic or recurrent disease continue to fare poorly, highlighting the need for more effective therapy. In addition, long-term effects of conventional chemotherapy such as infertility, heart failure, and second malignancy can threaten the quality and duration of life following cancer cure. To improve efficacy and reduce toxicity, pediatric oncologists have looked to precision oncology, a therapeutic approach that targets specific molecular features of tumors to customize treatment decisions beyond what is dictated by histologic diagnosis. 
Precision oncology has already transformed the treatment of many adult cancers, fueled by the development of genetic testing that allows for detection of actionable molecular changes present in diseases such as breast cancer, melanoma, and lung cancer. The increasing use of genetic testing platforms has improved our understanding of the specific molecular signatures of pediatric solid tumors, allowed for the comparison between initial and relapsed specimens, and directed the development of new inhibitors for emerging targets [6-9]. In addition, genetic testing of tumor tissue has resulted in the sub-classification of some tumor types into separate strata with molecular changes and corresponding specific therapies $[7,10,11]$. Precision oncology employs a wide array of treatment strategies, including monoclonal antibodies as well as small molecules targeting receptor tyrosine kinases (RTKs) or intracellular proteins. RTK inhibitors comprise the largest category of targeted agents and their application for the treatment of extracranial pediatric solid tumors is the focus of this review.

RTKs are protein complexes comprised of a transmembrane component that links the extracellular receptor with the intracellular catalytic kinase domain [12]. When a ligand binds to the extracellular receptor, it induces a conformational change that promotes autophosphorylation of the intracellular kinase and subsequent activation of downstream pathways. These pathways are involved in important cellular and biologic processes such as cell proliferation and angiogenesis [12-15]. Examples of RTK families include vascular endothelial growth factor receptor (VEGFR), epidermal growth factor receptor (EGFR), fibroblast growth factor receptor (FGFR), rearranged during transfection (RET), anaplastic lymphoma kinase (ALK), hepatocyte growth factor receptor (c-MET), and the tropomyosin receptor kinase (TRK). Alterations in RTKs may promote oncogenesis and metastasis through the overexpression of functionally normal RTKs, mutations within RTKs that render them constitutively active, or chromosomal translocations resulting in fusion proteins with conformational changes $[13,16,17]$.

Small molecule RTK inhibitors were some of the first examples of successful targeting of tumor-specific genetic changes, as demonstrated by the use of imatinib to inhibit the activity of the BCR-ABL fusion tyrosine kinase that defines chronic myeloid leukemia [18]. Drugs such as imatinib typically act on the intracellular domain of the RTK by interfering with the ATP binding site and preventing phosphorylation. However, since different RTKs may have similar intracellular domains, single inhibitors sometimes lack fidelity and alter the function of more than one RTK. For example, imatinib also has activity against tumors with activating mutations of KIT, such as gastrointestinal stromal tumors [19]. Since imatinib first received regulatory approval for use in 2001, there have been over 40 RTK inhibitors approved worldwide [16]. More detailed information on the specific activities and different mechanistic classes of RTKs can be found in other reviews [12,20].

Despite the availability of dozens of agents, there have only been a few successful adaptations to date of RTK inhibitors to treat extracranial pediatric solid tumors. This is likely because childhood solid tumors have fewer potentially targetable mutations in RTK pathways [8] and there are fewer pediatric cancer patients to participate in clinical trials. The greatest clinical benefit has been observed when treating tumors in which RTKs are activated through mutation or translocation. Outside of this context, the activity of these agents is limited by innate and acquired resistance and suffers from the lack of predictive biomarkers [16].

In this manuscript, we review seminal trials of RTK inhibitors for treating extracranial pediatric solid tumors, highlight the few established predictive biomarkers that guide therapy, and discuss the considerable knowledge gaps that remain. In addition to identifying the "who" (which patients may benefit the most from RTK inhibition), we must also discover more about the "when" (timing of therapy within the disease course) and the "how" (role for single-agent versus combination therapy) of RTK inhibition in order to optimize the precision of this treatment approach. 


\section{Key Clinical Trials of RTK Inhibitors to Treat Pediatric Solid Tumors}

RTKs are attractive targets for inhibition because they drive oncogenesis and angiogenesis in many pediatric solid tumors through effects on tumor cells and the microenvironment [21-23]. The antitumor benefit of RTK inhibitors is directly related to how essential the inhibited RTK is to tumor growth and viability and how effectively the target is inhibited. The former is dependent on tumor biology and the presence of resistance mechanisms, while the latter is dependent on drug choice and pharmacokinetic considerations. These variables account for the broad range of activity seen in pediatric studies to date. A summary of selected completed studies is presented in Table 1.

Table 1. Select completed trials of receptor tyrosine kinase inhibitors for pediatric solid tumors ${ }^{\dagger}$.

\begin{tabular}{|c|c|c|c|c|}
\hline Agent & Key Targets Inhibited & Relevant Tumors & $\begin{array}{l}\text { Key Toxicities } \\
\text { (Grade 3-4) }\end{array}$ & Comments \\
\hline $\begin{array}{l}\text { Larotrectinib } \\
{[\quad[24,25]}\end{array}$ & $\begin{array}{l}\text { TRKA, TRB, TRKC } \\
\quad\left(\mathrm{IC}_{50} 5-11 \mathrm{nM}\right)\end{array}$ & $\begin{array}{c}\text { Infantile } \\
\text { fibrosarcoma, } \\
\text { salivary gland tumor, } \\
\text { mesoblastic } \\
\text { nephroma, } \\
\text { lymphoma, solid } \\
\text { tumors }\end{array}$ & $\begin{array}{c}\text { Transaminitis, } \\
\text { anemia, neutropenia }\end{array}$ & $\begin{array}{l}\text { 75-92\% ORR; } \\
\text { USFDA approved for } \\
\text { pediatric solid tumors } \\
\text { harboring NTRK gene } \\
\text { fusions }\end{array}$ \\
\hline $\begin{array}{c}\text { Crizotinib } \\
\text { [26-29] }\end{array}$ & $\begin{array}{c}\operatorname{ALK}\left(\mathrm{IC}_{50} 24 \mathrm{nM}\right) \\
\mathrm{c-MET}\left(\mathrm{IC}_{50} 5-20 \mathrm{nM}\right)\end{array}$ & ALCL, IMT, NBL & $\begin{array}{l}\text { Neutropenia, } \\
\text { diarrhea }\end{array}$ & $\begin{array}{c}>80 \% \text { ORR for ALCL or IMT; } \\
9 \% \text { ORR for NBL; } \\
\text { USFDA approved for } \\
\text { relapsed ALK+ ALCL ages } \\
1-21 \text { years }\end{array}$ \\
\hline $\begin{array}{l}\text { Entrectinib } \\
\text { [30-32] }\end{array}$ & $\begin{array}{c}\text { ALK }\left(\mathrm{IC}_{50} 12 \mathrm{nM}\right) \\
\text { TRKA-C (IC } 501-5 \mathrm{nM}) \\
\text { ROS1 }\left(\mathrm{IC}_{50} 7 \mathrm{nM}\right)\end{array}$ & $\begin{array}{l}\text { NBL, salivary gland } \\
\text { tumor, sarcoma, } \\
\text { thyroid cancer }\end{array}$ & $\begin{array}{l}\text { Fatigue, weight gain, } \\
\text { transaminitis, } \\
\text { myelosuppression, } \\
\text { hyperuricemia }\end{array}$ & $\begin{array}{c}57 \% \text { ORR; } \\
\text { USFDA approved for } \\
\text { patients age } \geq 12 \text { years with } \\
\text { metastatic/unresectable } \\
\text { solid tumors harboring } \\
\text { NTRK gene fusions }\end{array}$ \\
\hline $\begin{array}{c}\text { Selpercatinib } \\
{[33,34]}\end{array}$ & $\operatorname{RET}\left(\mathrm{IC}_{50} 4 \pm 2 \mathrm{nM}\right)$ & $\begin{array}{c}\text { Thyroid cancer, } \\
\text { malignant peripheral } \\
\text { nerve sheath tumors, } \\
\text { sarcomas }\end{array}$ & $\begin{array}{l}\text { Hypertension, } \\
\text { diarrhea, } \\
\text { transaminitis, } \\
\text { prolonged QT } \\
\text { interval on } \\
\text { electrocardiogram }\end{array}$ & $\begin{array}{c}69-79 \% \text { ORR; } 64-92 \% \text { PFS at } \\
1 \text { year; } \\
\text { USFDA approved for } \\
\text { RET-mutant thyroid cancers } \\
\text { in patients age } \geq 12 \text { years }\end{array}$ \\
\hline $\begin{array}{c}\text { Cabozantinib } \\
{[35,36]}\end{array}$ & $\begin{array}{c}\text { VEGFR2 }\left(\mathrm{IC}_{50} 0.035 \mathrm{nM}\right) \\
\mathrm{c}-\mathrm{MET}\left(\mathrm{IC}_{50} 1.3 \mathrm{nM}\right) \\
\text { KIT }\left(\mathrm{IC}_{50} 4.6 \mathrm{nM}\right) \\
\text { RET }\left(\mathrm{IC}_{50} 5.2 \mathrm{nM}\right)\end{array}$ & $\begin{array}{l}\text { Ewing sarcoma, } \\
\text { osteosarcoma }\end{array}$ & $\begin{array}{l}\text { Hypophosphatemia, } \\
\text { transaminitis, HFSR, } \\
\text { pneumothorax, } \\
\text { neutropenia }\end{array}$ & $\begin{array}{l}\text { Osteosarcoma: } 17 \% \text { ORR, } \\
\text { with PFS } 52 \% \text { at } 6 \text { months } \\
\text { Ewing sarcoma: } 26 \% \text { ORR; } \\
\text { with PFS } 33 \% \text { at } 6 \text { months }\end{array}$ \\
\hline $\begin{array}{l}\text { Regorafenib } \\
\quad[37-41]\end{array}$ & $\begin{array}{c}\text { VEGFR1/2 }\left(\mathrm{IC}_{50} 4.2-13 \mathrm{nM}\right) \\
\text { KIT }\left(\mathrm{IC}_{50} 7 \mathrm{nM}\right) \\
\text { RET }\left(\mathrm{IC}_{50} 1.5 \mathrm{nM}\right) \\
\text { PDGFR } \beta\left(\mathrm{IC}_{50} 22 \mathrm{nM}\right)\end{array}$ & $\begin{array}{l}\text { Ewing sarcoma, } \\
\text { osteosarcoma }\end{array}$ & $\begin{array}{l}\text { Fatigue, chest pain, } \\
\text { hypophosphatemia, } \\
\text { HFSR, hypertension, } \\
\text { alkaline phosphatase, } \\
\text { myelosuppression, } \\
\text { diarrhea, mucositis, } \\
\text { hypertension }\end{array}$ & $\begin{array}{c}\text { Osteosarcoma: ORR } 8-14 \% \text {, } \\
\text { with } 44-62 \% \text { PFS at } 4 \text { months } \\
\text { Ewing sarcoma: ORR } \\
\text { 10-22\%; } 56 \% \text { PFS at } 8 \text { weeks, } \\
26 \% \text { PFS at } 6 \text { months }\end{array}$ \\
\hline $\begin{array}{l}\text { Lenvatinib } \\
{[42,43]}\end{array}$ & $\begin{array}{c}\text { VEGFR2 }\left(\mathrm{IC}_{50} 4 \mathrm{nM}\right) \\
\text { RET }\left(\mathrm{IC}_{50} 6.4 \mathrm{nM}\right) \\
\text { PDGFR } \alpha\left(\mathrm{IC}_{50} 29 \mathrm{nM}\right) \\
\text { FGFR2 }\left(\mathrm{IC}_{50} 27 \mathrm{nM}\right)\end{array}$ & Osteosarcoma & Back pain, dyspnea & $\begin{array}{c}\text { ORR } 7 \% \text {, with } 33.3 \% \text { PFS at } \\
4 \text { months }\end{array}$ \\
\hline
\end{tabular}


Table 1. Cont.

\begin{tabular}{|c|c|c|c|c|}
\hline Agent & Key Targets Inhibited & Relevant Tumors & $\begin{array}{l}\text { Key Toxicities } \\
\text { (Grade 3-4) }\end{array}$ & Comments \\
\hline $\begin{array}{l}\text { Sorafenib } \\
\text { [44-46] }\end{array}$ & $\begin{array}{c}\text { VEGFR2 }\left(\mathrm{IC}_{50} 4 \mathrm{nM}\right) \\
\text { RET }\left(\mathrm{IC}_{50} 0.4 \mathrm{nM}\right) \\
\text { PDGFR } \alpha\left(\mathrm{IC}_{50} 18 \mathrm{nM}\right)\end{array}$ & Osteosarcoma & $\begin{array}{l}\text { HFSR, } \\
\text { thrombocytopenia, } \\
\text { anemia, creatine } \\
\text { kinase elevation }\end{array}$ & $\begin{array}{l}14 \% \text { ORR; } 46 \% \text { PFS at } \\
4 \text { months; } \\
\text { Six-month PFS increased } \\
\text { from } 29 \% \text { to } 45 \% \text { with the } \\
\text { addition of everolimus }\end{array}$ \\
\hline Apatinib $[47,48]$ & $\begin{array}{l}\text { VEGFR2 }\left(\mathrm{IC}_{50} 1 \mathrm{nM}\right) \\
\text { RET }\left(\mathrm{IC}_{50} 13 \mathrm{nM}\right)\end{array}$ & Osteosarcoma & $\begin{array}{c}\text { Pneumothorax, } \\
\text { wound dehiscence, } \\
\text { proteinuria, diarrhea } \\
\text { HFSR }\end{array}$ & $\begin{array}{c}\text { ORR } 43 \% \text {, with } 57 \% \text { PFS at } \\
4 \text { months; }\end{array}$ \\
\hline $\begin{array}{l}\text { Pazopanib } \\
\text { [49-51] }\end{array}$ & VEGFR1 (IC 5010 nM) & $\begin{array}{l}\text { NRSTS given in } \\
\text { combination with } \\
\text { ifosfamide and } \\
\text { doxorubicin }\end{array}$ & $\begin{array}{l}\text { Myelosuppression, } \\
\text { febrile neutropenia, } \\
\text { sepsis, emesis, } \\
\text { wound dehiscence }\end{array}$ & $\begin{array}{c}58 \% \text { of patients treated with } \\
\text { pazopanib had pathological } \\
\text { response } \geq 90 \% \text { vs. } 22 \% \text { with } \\
\text { chemo alone }\end{array}$ \\
\hline
\end{tabular}

Legend: $\mathrm{IC}_{50}=$ half maximal inhibitory concentration, $\mathrm{nM}=$ nanomolar, $\mathrm{TRK}=$ tropomyosin receptor kinase, $\mathrm{ALK}=$ anaplastic lymphoma kinase, c-MET = hepatocyte growth factor receptor, RET = rearranged during transfection, VEGFR = vascular endothelial growth factor receptor, PDGFR = platelet-derived growth factor receptor, FGFR $=$ fibroblast growth factor receptor, ORR $=$ overall response rate, PFS = progression-free survival, USFDA = United States Food and Drug Administration, ALCL = anaplastic large cell lymphoma, $\mathrm{IMT}=$ inflammatory myofibroblastic tumor, NBL = neuroblastoma, NRSTS = non-rhabdomyosarcoma soft-tissue sarcoma, HFSR = handfoot skin reaction, ${ }^{+}=$due to trial design these results include a significant number of adult patients.

\subsection{Targeting Oncogenesis in Tumors with Mutations, Fusions, or Amplifications}

The most dramatic benefits from RTK inhibition are observed when there is substantial disruption of a key signaling pathway that uniquely drives tumor growth. An example of this has been the use of larotrectinib to treat tumors driven by fusions involving one of three isoforms of neurotrophic tropomyosin receptor kinase (NTRK). These genes encode the tropomyosin receptor kinase proteins TRKA, TRKB, and TRKC and partner with a variety of other genes to produce fusion proteins causing constitutive activation of the TRK proteins and subsequent signaling through various downstream pathways such as Ras-Raf-MAPK and PI3K-AKT-mTOR to drive oncogenic growth.

Larotrectinib is a highly selective agent that blocks the ATP-binding site of TRKA, B, and $C$ receptors with a half maximal inhibitory concentration $\left(\mathrm{IC}_{50}\right)$ of 5-11 nanomolar [52]. Preclinical testing confirms in vitro induction of apoptosis and G1 cell cycle arrest and dosedependent tumor inhibition is observed in mice bearing tumors with NTRK fusions [53]. In 2018, Drilon and colleagues published a landmark study of 55 patients with NTRK fusions ranging in age from 4 months to 76 years and spanning 17 different tumor histologies. Remarkably, the centrally-confirmed response rate was $75 \%$, with $71 \%$ of responses ongoing at one year [24]. The median time for response was at the first 8-week scheduled assessment and responses were independent of the specific partners involved in the translocation. These results resulted in larotrectinib approval by the US Food and Drug Administration (FDA) as a tissue agnostic therapy for patients of any age with a documented NTRK fusion.

NTRK gene fusions occur in approximately $1 \%$ of all solid tumors [54] and are spread across many tumor types in adults. In children, NTRK fusions are enriched in specific histologies. For example, infantile fibrosarcoma, congenital mesoblastic nephroma, and secretory carcinoma of the breast or salivary gland frequently have NTRK fusions identified [55-57]. These fusions are also present in some spindle cell sarcomas, spitzoid melanocytic tumors, and pediatric thyroid cancer [58,59]. Each of these diagnoses is rare when individually considered, however, the marked benefit seen to date with larotrectinib suggests that pediatric oncologists should consider testing for NTRK fusions when caring for patients with these tumor types. For infantile fibrosarcoma patients with NTRK fusions, the neoadjuvant use of larotrectinib may facilitate surgical resection and potentially spare young children the long-term toxicities of alkylator and anthracycline therapy [60]. This shift in treatment paradigm shows the potential impact of RTK inhibition when provided in 
the optimum clinical context of a highly specific agent treating an oncogene-addicted tumor. However, it should be emphasized that not all NTRK fusions identified by sequencing are functional or would be expected to respond to a RTK inhibitor. For example, in a genetic screen of 113 banked osteosarcoma tumor samples, three $(2.7 \%)$ had NTRK fusions although none were functional [61]. The authors hypothesized that the inherent chromosomal instability of osteosarcoma increases the likelihood of random passenger mutations and caution should be applied when assessing the potential treatment implications of agents targeting such fusions in which there are no signs of RNA or protein expression. In fact, immunostaining using a pan-TRK antibody has emerged as a highly sensitive and specific method of screening tumor samples for possible NTRK fusions and some authors suggest performing immunohistochemistry first followed by molecular confirmation of positive cases as a method to better identify functional fusions [55].

Hong et al. recently reported an expansion of the initial larotrectinib study to include 153 evaluable patients aged from 1 month to 84 years [25]. Similar findings were again observed with a centrally reviewed response rate of $79 \%$, including $16 \%$ with complete responses. The median duration of response was 35 months and responses were observed in patients with intracranial metastases, suggesting adequate central nervous system penetration. Despite the impressive response rates, resistance can still occur. Mutations in the ATP-binding site side of the kinase account for some cases of primary or acquired resistance and are termed "solvent front" mutations as they affect the solvent-exposed portion of the kinase domain and sterically interfere with drug binding [24]. These findings have resulted in the development of next-generation agents, such as selitrectinib and repotrectinib, that are specifically designed to overcome these issues $[52,62,63]$.

Other notable successes in pediatric solid tumors include targeting the $A L K$ fusions observed in the majority of anaplastic large cell lymphoma (ALCL) and approximately half of the patients with inflammatory myofibroblastic tumors (IMT) [64,65]. Crizotinib is a first-in-class ALK inhibitor that also has activity against MET and ROS1. A pediatric phase I study of crizotinib identified responses in ALCL and IMT [26], resulting in a phase II expansion of these cohorts. That study included 26 patients with relapsed/refractory ALCL and 14 patients with inoperable/metastatic IMT [27]. Responses were observed in over $80 \%$ of both cohorts and were often durable. The median time to response was within the first month of therapy. These findings resulted in the 2021 FDA approval of crizotinib for the treatment of relapsed ALCL in pediatric patients.

Crizotinib has also shown activity in some pediatric patients with $A L K$ point mutations or amplification ( $>10$ copies), which are observed in $14 \%$ of neuroblastoma patients and associated with the worse outcomes $[10,66]$. In this disease, $A L K$ mutations occur at different sites, which correlate with variable sensitivity to crizotinib based on different ATPbinding affinities of the $A L K$ mutations [67]. This laboratory finding was reflected clinically in a phase I trial of crizotinib showing response in only a subset of relapsed neuroblastoma patients [26]. One method to address resistance is to combine crizotinib with standard chemotherapy drugs and in preclinical studies this strategy produces responses even in crizotinib-resistant models [68]. This strategy is being pursued in an ongoing phase III trial for newly-diagnosed high-risk neuroblastoma patients with amplification or mutation of $A L K$ who will receive crizotinib in combination with all planned adjuvant therapy (ClinicalTrials.gov Identifier: NCT03126916, Table 2). 
Table 2. Select ongoing clinical trials of receptor tyrosine kinase inhibitors in pediatric solid tumors.

\begin{tabular}{|c|c|c|c|}
\hline Agent & Disease & $\begin{array}{l}\text { Study Population and } \\
\text { Additional Details }\end{array}$ & $\begin{array}{l}\text { ClinicalTrials.gov } \\
\text { Identifier }\end{array}$ \\
\hline Crizotinib & $\begin{array}{c}A L K \text {-altered } \\
\text { neuroblastoma }\end{array}$ & $\begin{array}{l}\text { Newly diagnosed, } \\
\text { high-risk patients; given } \\
\text { with standard therapy }\end{array}$ & NCT03126916 \\
\hline Ensartinib & $\begin{array}{c}A L K-\text { or } \\
\text { ROS1-altered solid } \\
\text { tumors, histiocytic } \\
\text { disorders }\end{array}$ & $\begin{array}{c}\text { Recurrent/refractory } \\
\text { advanced disease; } \\
\text { investigating biomarkers }\end{array}$ & NCT03213652 \\
\hline Entrectinib & $\begin{array}{l}\text { NTRK } 1 / 2 / 3 \text { or } R O S 1 \\
\text { fusion-positive } \\
\text { solid tumors }\end{array}$ & $\begin{array}{c}\text { Recurrent/refractory } \\
\text { disease }\end{array}$ & NCT02650401 \\
\hline Erdafitinib & $\begin{array}{l}\text { FGFR-mutated solid } \\
\text { tumors, NHL, } \\
\text { histiocytic disorders }\end{array}$ & $\begin{array}{l}\text { Recurrent/refractory } \\
\text { advanced disease }\end{array}$ & NCT03210714 \\
\hline Larotrectinib & $\begin{array}{c}\text { NTRK } \\
\text { fusion-positive } \\
\text { solid tumors, NHL, } \\
\text { histiocytic disorders }\end{array}$ & $\begin{array}{l}\text { Recurrent or refractory } \\
\text { advanced disease }\end{array}$ & NCT03213704 \\
\hline Lenvatinib & $\begin{array}{l}\text { Phase I: all solid } \\
\text { tumors } \\
\text { Phase II: Ewing } \\
\text { sarcoma, rhab- } \\
\text { domyosarcoma }\end{array}$ & $\begin{array}{c}\text { Recurrent/refractory } \\
\text { disease; } \\
\text { given with everolimus }\end{array}$ & NCT03245151 \\
\hline Lorlatinib & $\begin{array}{c}A L K \text {-altered } \\
\text { neuroblastoma }\end{array}$ & $\begin{array}{l}\text { Phase I, alone or in } \\
\text { combination with } \\
\text { conventional } \\
\text { chemotherapy }\end{array}$ & NCT03107988 \\
\hline Regorafenib & $\begin{array}{l}\text { Multiple bone and } \\
\text { soft tissue sarcoma } \\
\text { types }\end{array}$ & $\begin{array}{l}\text { Recurrent/refractory } \\
\text { advanced disease }\end{array}$ & NCT02048371 \\
\hline Regorafenib & Osteosarcoma & $\begin{array}{c}\text { Recurrent/refractory } \\
\text { disease; } \\
\text { given with nivolumab }\end{array}$ & NCT04803877 \\
\hline Repotrectinib & $\begin{array}{l}\text { Solid tumors with } \\
\text { ALK, ROS1, or } \\
\text { NTRK } 1 / 2 / 3 \\
\text { alterations }\end{array}$ & $\begin{array}{c}\text { Recurrent/refratcory } \\
\text { disease }\end{array}$ & NCT04094610 \\
\hline Selpercatinib & $\begin{array}{c}\text { RET-altered solid } \\
\text { tumors, } \\
\text { lymphomas, } \\
\text { histiocytic disorders }\end{array}$ & $\begin{array}{l}\text { Recurrent/refractory } \\
\text { advanced disease }\end{array}$ & NCT04320888 \\
\hline Sorafenib & $\begin{array}{l}\text { Hepatocellular } \\
\text { carcinoma }\end{array}$ & $\begin{array}{c}\text { Newly diagnosed } \\
\text { advanced disease; } \\
\text { given with chemotherapy }\end{array}$ & NCT03017326 \\
\hline Ceritinib & $\begin{array}{c}\text { ALK-altered } \\
\text { neuroblastoma }\end{array}$ & $\begin{array}{l}\text { Recurrent/refractory } \\
\text { disease; } \\
\text { given with ribociclib }\end{array}$ & NCT02780128 \\
\hline
\end{tabular}

Other strategies to address resistance include the development of second-generation and third-generation ALK inhibitors such as alectinib, ceritinib, lorlatinib, and ensartinib. Preclinical testing of these drugs has demonstrated activity in cell lines or xenograft models that harbor $A L K$ mutations resistant to crizotinib [69-72] and anecdotal reports and early 
phase I trials showing clinical activity are now starting to appear [70,73-75]. Another drug, entrectinib, is a multi-targeted RTK inhibitor with action not only against ALK but also the TRK-B receptor, which is expressed in over half of high-risk neuroblastoma tumors and associated with a poor prognosis [76]. Entrectinib received FDA approval based on high response rates seen in patients 12 years and older with NTRK, ROS1, or $A L K$ fusions [77]. Its impact against neuroblastoma through targeting $A L K$ mutations or TRK-B expression is under further investigation [78]. More comprehensive reviews of ALK-targeted therapy in neuroblastoma are available $[10,30]$. The evolution of agents and ability for more precise selection based on specific mutations is similar to the development of therapies for gastrointestinal stromal tumor in which resistance to the primary RTK inhibitor (imatinib) resulted in the selective incorporation of later-generation drugs with activity against specific mutations [19].

Other RTK proto-oncogenes such as RET are altered in pediatric solid tumors and may be potentially targetable. RET mutations and fusions have been documented in pediatric thyroid cancer and are associated with a more aggressive phenotype via downstream signaling through MAPK, PI3K, and JAK-STAT [79,80]. Multi-kinase inhibitors of RET, including cabozantinib and vandetanib, have modestly improved survival in patients with medullary thyroid cancer (MTC), but their toxicity may limit the durability of benefit [81,82]. In contrast, LOXO-292 (selpercatinib) is a highly selective RET inhibitor with compelling activity even in patients previously treated with other RTK inhibitors. Furthermore, the narrow spectrum of inhibition results in less toxicity, with only $2 \%$ of patients withdrawing because of the side effects [33]. These results have resulted in approval for patients over 12 years of age with $R E T$-mutant or fusion-positive advanced thyroid cancer requiring systemic therapy.

Fibroblast growth factor receptor (FGFR) is a family of RTKs with downstream targets that promote cell proliferation, survival, and migration, including MAPK and PI3K [83]. FGFR is often overexpressed or mutated in rhabdomyosarcoma [84]. Erdafitinib is a panFGFR inhibitor with activity at levels as low as 1 nanomolar [85] and is approved for the treatment of metastatic urothelial cancer in adults. A prospective phase II trial for pediatric solid tumors with FGFR alterations is now being conducted (NCT03210714, Table 2). FGFR signaling also plays a prominent role in angiogenesis, which provides an alternative avenue for the use of RTK inhibitors [14].

\subsection{Targeting Angiogenesis and Non-Mutated RTKs}

Even when an activating mutation or gene fusion is not identified in tumor cells, RTK inhibitors still may be useful although durable benefit is less likely. This strategy has primarily focused on targeting angiogenesis, which is the main mechanism for the new blood vessel development that is essential for tumor growth and metastasis. Although this process is complex and driven by many factors, signaling through the vascular endothelial growth factor receptor 2 (VEGFR2) is particularly important [86]. VEGFR2 is often overexpressed by the endothelial cells of solid tumors and can be inhibited at low nanomolar levels by several of the RTK inhibitors used to treat pediatric solid tumors even in the absence of a defined gene mutation or fusion. In this manner, the RTK inhibitor is acting to disrupt the supply of nutrients to the tumor rather than directly inhibiting a specific oncologic driver.

Among extracranial pediatric solid tumors, RTK inhibitors targeting angiogenesis have most often been used for therapy of recurrent sarcoma. This strategy is partly modeled after the use of pazopanib to treat adult soft tissue sarcoma. Pazopanib was initially identified through a screening process for VEGFR2 inhibitors. However, similar to many of the agents used for sarcoma, pazopanib is a multi-kinase inhibitor that also inhibits plateletderived growth factor receptor (PDGFR) and c-KIT at $<100$ nanomolar, with slightly less inhibition of FGFR [87]. These additional tyrosine kinases may promote growth through mechanisms other than angiogenesis and preclinical studies in a variety of models suggest that pazopanib has activity not only in tumor-associated endothelial cells and angiogenesis 
but also directly on tumor cells as well as the tumor microenvironment [88]. Early phase clinical trials of pazopanib showed disease stability in adult sarcoma patients and in a randomized phase III trial, pazopanib demonstrated improved progression-free survival from 1.6 to 4.6 months when compared to the placebo in adults with advanced soft tissue sarcoma [89]. Although this finding resulted in regulatory approval, the objective response rate was low $(6 \%)$ and the overall survival was not statistically different.

The approval of pazopanib in adults stimulated further interest in using multi-RTK inhibitors for pediatric sarcomas. Supporting this was the potential importance of angiogenesis in osteosarcoma and Ewing sarcoma [90,91], as well as the expression of targetable RTKs such as RET, MET, PDGFR, KIT, AXL, and FGFR. The experience of several recent phase II trials of multi-targeted RTK inhibitors for the treatment of recurrent osteosarcoma and Ewing sarcoma has been summarized [92]. The drugs studied included sorafenib, apatinib, lenvatinib, cabozantinib, and regorafenib $[35,37,38,40,42,44]$. These agents all have variable inhibitory effects on the kinases noted above and several important observations can be made. First, as observed with pazopanib, objective responses were generally modest in number and nearly always partial, with the primary clinical benefit being improved progression-free survival compared to either placebo or historical controls. This higher rate of primary and secondary resistance is in contrast to studies targeting specific RTK fusions mentioned previously, in which responses were more frequent and durable. Secondly, the toxicity of these multi-RTK inhibitors can be considerable, with much higher rates of dose reductions and treatment discontinuation than observed in agents such as larotrectinib. These side effects can negatively affect quality of life even in patients who are having an oncologic response $[47,93]$ and some toxicities such as pneumothorax seen in patients with pulmonary metastases may require hospitalization and/or invasive interventions. Third, there is variability with respect to clinical benefits between agents, suggesting that some targets may perhaps be better suited for therapy of these two diseases. Tian et al. suggested that a careful review of the level of inhibition provided for each target coupled with the results of recent clinical trials could help identify the most relevant RTKs for targeting [46]. For example, the activity of imatinib is quite limited in osteosarcoma [94], suggesting that the inhibition of KIT and PDGFR may be inferior targets. By contrast, all five of the agents with activity against bone sarcoma inhibited VEGFR2 and RET at concentrations $<15$ nanomolar, while imatinib's inhibition of these targets is much more limited. This strategy of exclusion based on the spectrum of target inhibition and clinical trial performance is one method to begin the rational selection of agents, but in the absence of a specific mutation or fusion the method involves inference based on small studies of heavily pretreated patients without direct comparisons between such agents. Stated in another manner, it remains very difficult to know the critical nature of any particular target in these tumor types and it is clear that the simple expression of a target is not sufficient to guarantee a high likelihood of clinical benefit. Similarly unknown is the extent of target inhibition necessary for successful treatment and this may in part depend on pharmacokinetic and pharmacodynamic properties of the drug as well as patient tolerance.

Despite these uncertainties, the disease stabilization observed in multiple relapsed patients does suggest that multi-RTK inhibitors may ultimately have a further role in therapy for bone sarcoma. In other pediatric solid tumors, results have been less consistent. Occasional remarkable responses have been observed in patients with recurrent neuroblastoma treated with imatinib [95], as well as multiple recurrent Wilms tumor patients with overexpression of RET and MET who responded to cabozantinib [96]. However, in a larger cooperative group phase II trial of imatinib, no responses were observed in patients with neuroblastoma, desmoplastic small round cell tumor, or synovial sarcoma [94]. Similarly, no responses were observed for sorafenib in patients with relapsed Wilms tumor or rhabdomyosarcoma [97]. In a preliminary report of a Children's Oncology Group (COG) study of cabozantinib, activity was confirmed for patients with recurrent osteosarcoma, but not seen in those with Ewing sarcoma, rhabdomyosarcoma, other soft tissue sarcoma, or Wilms tumor [36]. Results from a COG study of pazopanib for patients with relapsed osteosar- 
coma, Ewing sarcoma, rhabdomyosarcoma, other soft tissue sarcoma, neuroblastoma, or hepatoblastoma have not yet been reported (NCT01956669). Finally, given that sorafenib has received regulatory approval for advanced hepatocellular carcinoma, anecdotal use of this agent has been reported in children with liver cancers $[98,99]$. The combination of sorafenib with conventional chemotherapy for treatment of pediatric hepatocellular carcinoma is being prospectively assessed in an ongoing international trial (NCT03017326, Table 2).

The use of RTK inhibitors has also been investigated for treatment of other uncommon pediatric solid tumors. Although germ cell tumors have been reported to express c-KIT and PDGFR, inhibitors such as sunitinib, pazopanib, and sorafenib have shown only limited activity [100]. In contrast, sorafenib appeared beneficial for treatment of adults with desmoid tumors, with a response rate of $33 \%$ and a doubling of the 2 year PFS compared to the placebo [101]. The use of sorafenib or pazopanib is now being explored for younger patients as well [102,103].

Another method for targeting angiogenesis in solid tumors is the use of bevacizumab, a monoclonal antibody that binds to VEGF and interferes with binding to VEGFRs. This strategy has a different mechanism of inhibition that is narrower than observed with RTK inhibitors. Previous studies have shown limited activity of bevacizumab as a single agent [104] and in combination with chemotherapy for pediatric sarcoma $[105,106]$. However, no direct comparisons of anti-VEGF antibodies versus RTK inhibitors in pediatric solid tumor patients have been reported.

\subsection{Targeting Tumor Microenvironment}

Aberrant angiogenesis can promote a hostile tumor microenvironment that is hypoxic and acidotic [107]. RTKs have been shown to modulate non-endothelial components of the tumor microenvironment through complex mechanisms such as the enhancement of antitumor immunity and local immune cell populations [23]. One example is the role of VEGF in creating an immunosuppressive environment through the recruitment of myeloidderived suppressor cells and regulatory $\mathrm{T}$ cells, as well as the inhibition of dendritic cell maturation and antigen presentation [108]. A deeper understanding of the tumor microenvironment and its role in cancer is required to aid in the design of future clinical trials.

To begin to address these complicated changes, Wilky et al. combined the VEGFR inhibitor axitinib with the anti-programmed death 1 (PD-1) antibody pembrolizumab to treat adults with sarcoma [109]. The 3 month PFS of $65 \%$ and response rate of $25 \%$ exceeded historical expectations. Similarly encouraging preliminary results were also observed with a trial of sunitinib and the anti-PD-1 antibody nivolumab for adult bone sarcoma [110]. Additional studies are underway to further assess the ability of RTK inhibitors to synergize with immunotherapies, such as a trial of regorafenib and nivolumab for patients with recurrent osteosarcoma (NCT04803877, Table 2). However, there is a potential that combination therapy may exacerbate toxicity, as observed in a study combining crizotinib and nivolumab in lung cancer patients which was terminated early due to severe hepatic toxicity [111].

\section{Intrinsic and Acquired Resistance}

Resistance remains the greatest barrier to improving the clinical benefit of RTK inhibitors. Resistance can be intrinsic, in which tumors continue to grow despite treatment, or acquired, in which initially responding or stable tumors developed progression over time. Although pediatric tumors with mutation-driven or fusion-driven oncogenesis are often initially responsive to RTK inhibition, certain specific mutations seem inherently resistant. Examples include mutations in ALK (e.g., F1174L) or NTRK that have driven development of later-generation inhibitors described earlier. Another cause of primary resistance is the absence of protein expression despite molecular evidence of gene fusion, as observed in some patients with certain NTRK fusions whose tumors are resistant to 
larotrectinib [24]. Finally, RTK inhibitors are not effective if the target is not essential to the growth of the tumor. This issue likely is the cause for most intrinsic resistance to the multi-RTK inhibitors used for sarcoma, in which the inhibition of targets that are expressed or even amplified is not enough to stop the growth of the tumor.

Acquired resistance may also develop from several different mechanisms, such as the later development of mutations in the primary target, the development of alternate signaling pathways that drive tumor growth, or the expression of drug resistance proteins. These various scenarios are reviewed in more detail elsewhere $[17,112]$. Understanding these mechanisms can sometimes result in improved treatment. For example, the multikinase inhibitor sorafenib produced objective responses in $14 \%$ of patients with recurrent osteosarcoma, but by 6 months only $29 \%$ of patients were free of progression [44]. Upon further investigation, Pignochino and colleagues had demonstrated that sorafenib increases downstream mTORC2 signaling in osteosarcoma cells and in xenograft models this escape mechanism was abrogated with the mTOR inhibitor everolimus [113]. This laboratory observation was then translated to a clinical trial combining sorafenib and everolimus in which the 6 month progression-free survival was improved to 45\% [114]. In analogous works in high-risk neuroblastoma, molecularly selected patients are treated in an ongoing study with the ALK inhibitor ceritinib combined with the CDK4/6 inhibitor ribociclib based on preclinical evidence of synergy (NCT02780128, Table 2) [115].

Another proposed therapeutic strategy is the creation of a single drug to target two distinct pathways that are activated together in tumor cells. In high-risk neuroblastoma, $A L K$ mutations co-segregate with MYCN amplification, with the $A L K$ mutation driving its transcription and expression. Since inhibiting both oncogenic pathways with a single drug would be desirable, investigators have begun to identify candidate dual inhibitors with preclinical activity [116]. These approaches are laudable and are the logical next steps in drug development. However, resistance mechanisms are often complex and incompletely understood and even when downstream compensatory pathways are carefully documented in preclinical models of pediatric sarcoma [117], combined inhibition of seemingly relevant pathways are not always effective [118].

In an effort to overcome intrinsic resistance and to prevent the development of acquired resistance, investigators have also combined chemotherapy with RTK inhibitors in the laboratory and in the clinic $[51,68,119]$. Examples include the incorporation of crizotinib along with chemotherapy for patients with newly diagnosed $A L K$-altered high-risk neuroblastoma (NCT03126916, Table 2) and the randomized phase II screening trial of ifosfamide/doxorubicin with or without pazopanib in newly diagnosed non-rhabdomyosarcoma soft tissue sarcoma [51]. In the latter study, the addition of pazopanib was feasible and resulted in improved rates of pathologic necrosis at definitive resection, although the final impact on survival has not yet been reported. Combination therapy did increase the incidence of toxicity, but this was manageable.

Russo and colleagues combined pazopanib with a different standard chemotherapy backbone (vincristine plus irinotecan) in a single-arm study, identifying an objective response rate of $47 \%$ and median time to progression of 10 months in pediatric patients with various types of recurrent sarcoma [120]. However, when combining this same chemotherapy backbone with regorafenib, only sequential but not concomitant treatment was tolerated, perhaps because regorafenib can inhibit expression of UGT1A1 and increase toxicity of irinotecan [121]. Similarly, when pazopanib was added to temozolomide plus irinotecan, toxicity was considerable and a maximum tolerated dose could not be identified [119]. These results differed from those reported by Gaspar et al. regarding a phase I study of lenvatinib combined with ifosfamide and etoposide for patients with recurrent osteosarcoma, in which toxicity was more manageable and two-thirds of patients were progression-free at 4 months [42]. Finally, the pharmacokinetic properties of RTK inhibitors can be exploited therapeutically as shown by Furman et al. who used the EGFR inhibitor gefitinib to inhibit the drug resistance protein ABCG2, resulting in a four-fold increase in the bioavailability of oral irinotecan [122]. These early studies demonstrate that 
while adding RTK inhibitors to conventional chemotherapy is a rational strategy to try to overcome resistance, close attention to toxicity, dosing, sequencing, and drug interactions is necessary to optimize therapy. In addition, since these chemotherapy backbones already have some baseline level of activity, assessing the true benefit will require larger controlled studies, which are being planned by cooperative groups such as the COG for bone sarcomas. Examples of ongoing studies of RTK inhibitors to treat extracranial solid tumors are provided in Table 2.

\section{Toxicity, Dosing, and Pharmacokinetic Considerations}

The side effect profile of RTK inhibitors is different than that of conventional cytotoxic therapy and is generally related to the specific RTKs that are affected. For example, agents targeting VEGFR are commonly associated with hypertension, diarrhea, proteinuria, poor wound healing, and thyroid dysfunction, while those targeting ALK or MET may cause vomiting or pancreatic inflammation. The scope of toxicities can affect a wide range of organ systems and can include weight gain, dizziness, and pain upon withdrawal of therapy [123]. The incidence of toxicities may be related to the extent of various kinases inhibited. For example, highly-specific inhibitors such as larotrectinib and selpercatinib require dose reductions in less than $10 \%$ of patients $[25,33]$, while one-third or more of patients receiving multi-RTK inhibitors require treatment modifications [92].

The degree to which on-target toxicities such as these are associated with benefits in pediatric patients is unclear [93,124-126] since some side effects take time to develop and are therefore observed more in patients who do not have intrinsic resistance and early progression of disease. Given the continuous administration schedule used with most RTK inhibitors, the nature of toxicities can affect patients in a different manner than observed with conventional chemotherapy in which side effects are more acute but often substantially improve within a treatment cycle. In fact, sometimes toxicity results in an overall worse quality of life despite relatively high response rates, as observed in a recent study of apatinib for pediatric patients with recurrent osteosarcoma [47]. In addition, the true prevalence of side effects associated with RTK inhibitors may be underestimated [127]. Of special concern in pediatrics is the potential for impairment of critical developmental pathways in growing children, particularly if more lengthy therapy is given [128]. Long-term monitoring of linear growth, endocrine function, and cardiac function will be important to better understand the potential late effects of these agents in young patients.

Toxicities from RTK inhibitors are used in early phase clinical trials to determine dosing, which for the majority of oncology drugs is based on a maximum tolerated dose (MTD) assessed by first-cycle toxicity in early clinical trials. Given that cumulative toxicity may be a larger issue with RTK inhibitors and given that demonstration of a steep dose-response curve may be less clear with these drugs, some investigators have advocated for establishing an optimal biological dose (OBD) that identifies the lowest dose at which the desired biological effect is observed [129]. Understanding the activity of RTK inhibitors at a range of dosing may be important when combining these agents with chemotherapy backbones since lower doses are often necessary to maintain tolerability [27,51,130]. In other settings, the dose of RTK inhibitors may be increased until some secondary side effect occurs. For example, dose-dependent elevations in serum phosphate are seen as a marker of FGFR inhibition and therefore erdafitinib activity [131]. In clinical trials, the dose of erdafitinib has been increased if patients had no treatment-related effects and failed to reach a target serum phosphate level of $5.5 \mathrm{mg} / \mathrm{dL}$ [132]. There are several important pharmacokinetic considerations related to the use of RTK inhibitors. Many of these agents are metabolized through the CYP3A4 pathway, which may vary between individuals and be affected by concurrent medications. As with any oral drug, absorption may potentially be affected by food or the use of antacids that affects gastric $\mathrm{pH}$ [133-135]. In addition, treatment of young children often requires oral solutions instead of capsules or tablets. Some agents are not available in this formulation and for some medications such as pazopanib, there was a nearly three-fold difference in the MTD for the suspension compared to tablets [136]. Given 
these pharmacologic variabilities, as well as studies showing that $20 \%$ of adults receiving the recommended dose of pazopanib do not achieve therapeutic drug levels [137], some investigators have considered therapeutic drug monitoring [133]. This could prevent long periods of subtherapeutic dosing as well unnecessary overexposure, risk of toxicity and treatment cessation, which are associated with shortened PFS [138]. Monitoring could also resolve current discrepancies with regard to optimal dosing regimens, which may help balance survival and quality of life $[137,139]$. Widespread implementation of this practice will require a better understanding of the relationship between efficacy and toxicity to exposure for each RTK inhibitor, but provides an additional opportunity to personalize care for the cancer patient.

\section{Predictive Biomarkers and Clinical Trial Design}

The ability to molecularly profile tumors has dramatically increased our understanding of oncogenesis and therapeutic options. Results have now been reported from studies involving several hundred cumulative patients whose tumors were assessed with a variety of testing platforms $[6,7,140-142]$. Common conclusions from these studies include the following: (1) testing from fresh, frozen, or even paraffin-embedded tissue is feasible in a multi-institutional setting; (2) results using comprehensive panels for mutational analysis, gene fusions, and copy number alterations may be available within one month or less; (3) testing identifies specific therapeutic options or suggests changes in therapy in at least half of patients (depending on how one defines an actionable change); and (4) approximately one-fourth of patients with actionable findings are recommended therapy with an RTK inhibitor. Identification of a kinase fusion was the most common reason for recommending a RTK inhibitor, followed by the presence of an activating mutation. Importantly, there have been actionable changes in a wide variety of tumor types, including some that were unexpected and historically not responsive to conventional chemotherapy.

Outside of treatment for kinase fusions or activating mutations, the absence of similarly strong biomarkers likely dilutes the effectiveness of RTK inhibitors used to treat pediatric solid tumors without these features. It is clear that treatment is beneficial for some sarcoma patients, but we cannot yet reliably identify these patients in a prospective fashion. Combinations of DNA analysis, immunohistochemistry, and proteomic analysis have been proposed, but results are variable and have not been prospectively validated [143-145]. Direct measurement of serum proteins such as VEGFA or soluble MET may have some utility in predicting responsiveness to cabozantinib, but requires further confirmation [35].

When considering clinical trial design, cooperative group studies are now available which link potentially targetable findings with suitable agents. One large study is the National Cancer Institute-COG Pediatric MATCH study (NCT03155620), which expands the availability of molecular testing and drug availability to over 200 childhood cancer centers. This umbrella trial currently has 13 open arms, including four using RTK inhibitors for patients of any histology with defined targets as assessed by DNA and RNA sequencing: larotrectinib (NTRK), ensartinib (ALK and ROS), erdafitinib (FGFR), and selpercatinib (RET). In the first 1000 patients enrolled on the screening protocol, matches to an open arm were identified in $31 \%$ of patients [146]. This rate was higher than expected and may reflect enrollment of patients who had prior molecular testing given the commercial availability of testing platforms. Preliminary results have also been reported from the INFORM study involving eight European countries and over 1300 patients to date. Nearly one-fourth of patients had a very high $(8 \%)$ or high $(14.8 \%)$ priority target and patients with very high priority targets treated with matched therapy had improved time to progression [147].

Establishing meaningful assessment of clinical benefit will be important in clinical trial design. Traditional endpoints of phase II trials such as objective response rate may be less relevant than progression-free survival in some pediatric cancers $[148,149]$. For medullary thyroid cancer, assessment of carcinoembryonic antigen or calcitonin may be a surrogate biomarker for response [33]. Early assessment of metabolic response with 
functional imaging after one month of therapy with cabozantinib identified osteosarcoma and Ewing sarcoma patients with longer progression-free survival [35].

Treatment of pediatric solid tumor patients with RTK inhibitors has most often been performed in the setting of single-agent therapy used for recurrent measurable disease. Although this strategy allows for a cleaner assessment of activity, this therapy context may not be optimum for these agents. Given that the genetic landscape of many pediatric solid tumors at diagnosis is relatively simple, an argument has been made for an earlier introduction of these agents before the development of mutations resulting in treatment resistance [150]. Alternatively, maintenance use of RTK inhibitors in the setting of high-risk remission could also be considered given the prior success of using targeted therapy in the treatment of high-risk neuroblastoma in remission [151,152].

In regard to dosing, the Innovative Therapies for Children with Cancer consortium released a position paper outlining strategies for early phase clinical trial design for more rapid progress in emerging drug development [153]. Given that targeted therapies tend to have more class-related rather than dose-related toxicities, lengthy dose escalation phases may not be warranted. They recommend that pediatric dosing generally start at adult recommended phase II dose (RP2D) adjusted for body surface area (BSA) provided that this dose should be an equivalent dose of the minimum active target exposure. For drugs with more serious dose-related toxicities, beginning dose escalation at $80 \%$ of the adult $\mathrm{RP} 2 \mathrm{D}$ is warranted. Due to the wider therapeutic index of many targeted agents, the pediatric RP2D may not need to be as high as the MTD, unless a dose-activity relationship has been documented in adults. Expansion cohorts should be incorporated for populations of patients for whom there is a rational expectation of drug activity.

\section{Discussion and Conclusions}

The availability of molecular profiling over the past two decades has increased recognition of the potential ways precision medicine can be used for children with solid tumors. The frequency of actionable changes is less in children than adults, and many pediatric malignancies will unfortunately not have molecular changes that can be used to guide therapy. However, there is an important subset of pediatric extracranial solid tumors that do indeed have potentially druggable alterations $[8,140,154]$. While many of these alterations do not involve RTKs, there remains strong rationale for the use of RTK inhibitors in certain tumor types. For example, testing should be considered for tumors such as infantile fibrosarcoma and inflammatory myofibroblastic tumor that are known to be driven by kinase fusions, given that RTK inhibitors may now be used prior to conventional chemotherapy $[60,155]$. Similarly, the diagnosis of anaplastic large cell lymphoma or high-risk neuroblastoma often triggers testing for $A L K$ mutations that can help direct therapy. Pediatric thyroid cancers also frequently have kinase fusions that are amenable to targeted therapy in situations requiring medical management. In addition, clinicians often pursue testing in other recurrent or metastatic solid tumors in which conventional therapy is unlikely to be curative, with the hope of identifying the rare patient with unexpected actionable findings. However, the fact that many pediatric solid tumors do not have clearly identified predictive biomarkers remains an ongoing challenge for the use of precision medicine in this population.

Multiple questions about molecular testing are under further investigation. Given that kinase fusions represent the most important biomarker for use of RTK inhibitors, strong consideration should be given for testing that includes some method for their identification, such as RNA sequencing [150]. Other issues being explored include the identification and significance of subclones [156], the optimal timing of sample collection, the significance of tumor heterogeneity, and the ability to screen for biomarkers using circulating tumor cells and cell-free DNA [157,158]. It is clear that our level of testing and identification of more robust predictive biomarkers must improve in order for more patients to benefit from treatment with RTK inhibitors. For example, the combination of a high-throughput small molecule screen complemented with a genome-scale CRISPR-Cas9 gene-knockout screen recently identified several RTKs as therapeutic targets in pediatric rhabdoid tumors [159]. 
The choice of agent is often based on clinical availability. The median time lag from first-in-human to first-in-child trials for oncology agents is 6.5 years [160], although efforts are underway to hasten access of new drugs to children in the US as well as in developing countries [161,162]. Another access issue is drug formulation, as some younger children may have difficulty with therapy unless an oral solution is available, and even then this may not be tolerable [130]. As our knowledge base grows, we are now able to identify particular mutations which may respond only to second-generation or third-generation agents. Decisions about how RTK inhibitors are best utilized (single-agent or in combination) represent a balance of efficacy and toxicity. While single-agent therapy is very successful in certain contexts $[24,33]$, the combination with chemotherapy will likely be necessary for many RTK inhibitors in order to reduce primary and acquired resistance. These combinations will require close monitoring for toxicity and pharmacokinetic interactions and ultimately randomized trials will be necessary to more clearly assess the benefit of adding RTK inhibitors. Trials adding RTK inhibitors to immunotherapy offer an exciting new avenue for investigation, taking advantage of the effects seen in the tumor microenvironment. Larotrectinib has even been shown to restore the radioactive uptake of iodine in papillary thyroid cancer cells [163], potentially opening up additional lines of investigation.

Clinical trial design will remain a crucial element in optimizing use of these drugs through the identification of appropriate doses and scheduling. The timing of therapy, whether at induction, post-remission, or recurrence, will need to be carefully considered. Management of side effects will also be important given the variable pharmacokinetic profiles of these agents. Although some side effects may correlate with treatment benefit, the cumulative nature of toxicities can negatively affect quality of life. Additional questions remain relative to the appropriate length of therapy, especially for patients with incomplete responses who are tolerating therapy. For patients who go off therapy in remission but subsequently relapse, retreatment with the same RTK inhibitor may be considered although there is little information on this strategy to date [164].

In summary, in the 20 years since the first approval of imatinib, great progress has been made in the development of new drugs and the understanding of novel therapeutic targets. However, considerable knowledge gaps remain. It is important for pediatric oncologists to be aware that while the potential of precision medicine is being realized in a few specific pediatric solid tumors, much work remains to extend the applicability of RTK inhibitors through biomarker identification and thoughtful clinical testing.

Author Contributions: Both authors have contributed substantially to the preparation of this manuscript. All authors have read and agreed to the published version of the manuscript.

Funding: This manuscript received no external funding.

Institutional Review Board Statement: Not applicable.

Informed Consent Statement: Not applicable.

Data Availability Statement: No new data were created or analyzed in this study. Data sharing is not applicable to this article.

Conflicts of Interest: The authors declare no conflict of interest.

\section{References}

1. Matthay, K.K.; Maris, J.M.; Schleiermacher, G.; Nakagawara, A.; Mackall, C.L.; Diller, L.; Weiss, W. Neuroblastoma. Nat. Rev. Dis. Prim. 2016, 2, 16078. [CrossRef] [PubMed]

2. Brok, J.; Treger, T.D.; Gooskens, S.L.; Heuvel-Eibrink, M.M.V.D.; Pritchard-Jones, K. Biology and treatment of renal tumours in childhood. Eur. J. Cancer 2016, 68, 179-195. [CrossRef] [PubMed]

3. Borinstein, S.C.; Steppan, D.; Hayashi, M.; Loeb, D.M.; Isakoff, M.S.; Binitie, O.; Brohl, A.; Bridge, J.A.; Stavas, M.; Shinohara, E.T.; et al. Consensus and controversies regarding the treatment of rhabdomyosarcoma. Pediatr. Blood Cancer 2018, 65, e26809. [CrossRef] [PubMed] 
4. $\quad$ Reed, D.R.; Hayashi, M.; Wagner, L.; Binitie, O.; Steppan, D.A.; Brohl, A.; Shinohara, E.T.; Bridge, J.A.; Loeb, D.M.; Borinstein, S.C.; et al. Treatment pathway of bone sarcoma in children, adolescents, and young adults. Cancer 2017, 123, 2206-2218. [CrossRef] [PubMed]

5. Aronson, D.C.; Meyers, R.L. Malignant tumors of the liver in children. Semin. Pediatr. Surg. 2016, 25, 265-275. [CrossRef] [PubMed]

6. Lee, J.W.; Kim, N.K.D.; Lee, S.H.; Cho, H.W.; Ma, Y.; Ju, H.Y.; Yoo, K.H.; Sung, K.W.; Koo, H.H.; Park, W.-Y. Discovery of actionable genetic alterations with targeted panel sequencing in children with relapsed or refractory solid tumors. PLOS ONE 2019, 14, e0224227. [CrossRef] [PubMed]

7. Chang, W.; Brohl, A.S.; Patidar, R.; Sindiri, S.; Shern, J.F.; Wei, J.S.; Song, Y.K.; Yohe, M.E.; Gryder, B.; Zhang, S.; et al. MultiDimensional ClinOmics for Precision Therapy of Children and Adolescent Young Adults with Relapsed and Refractory Cancer: A Report from the Center for Cancer Research. Clin. Cancer Res. 2016, 22, 3810-3820. [CrossRef] [PubMed]

8. Gröbner, S.N.; Project, I.P.-S.; Worst, B.C.; Weischenfeldt, J.; Buchhalter, I.; Kleinheinz, K.; Rudneva, V.A.; Johann, P.D.; Balasubramanian, G.P.; Segura-Wang, M.; et al. The landscape of genomic alterations across childhood cancers. Nature 2018, 555, 321-327. [CrossRef] [PubMed]

9. Evans, W.E.; Pui, C.; Yang, J.J. The Promise and the Reality of Genomics to Guide Precision Medicine in Pediatric Oncology: The Decade Ahead. Clin. Pharmacol. Ther. 2020, 107, 176-180. [CrossRef]

10. Trigg, R.M.; Turner, S.D. ALK in Neuroblastoma: Biological and Therapeutic Implications. Cancers 2018, 10, 113. [CrossRef]

11. Juraschka, K.; Taylor, M.D. Medulloblastoma in the age of molecular subgroups: A review. J. Neurosurg. Pediatr. 2019, 24, 353-363. [CrossRef]

12. Krause, D.S.; Van Etten, R.A. Tyrosine Kinases as Targets for Cancer Therapy. N. Engl. J. Med. 2005, 353, 172-187. [CrossRef]

13. Gaumann, A.K.; Kiefer, F.; Alfer, J.; Lang, S.A.; Geissler, E.K.; Breier, G. Receptor tyrosine kinase inhibitors: Are they real tumor killers? Int. J. Cancer 2015, 138, 540-554. [CrossRef]

14. Katoh, M.; Nakagama, H. FGF Receptors: Cancer Biology and Therapeutics. Med. Res. Rev. 2014, 34, 280-300. [CrossRef]

15. Weinstein, I.B.; Joe, A.K. Mechanisms of Disease: Oncogene addiction-A rationale for molecular targeting in cancer therapy. Nat. Clin. Pr. Oncol. 2006, 3, 448-457. [CrossRef]

16. Huang, L.; Jiang, S.; Shi, Y. Tyrosine kinase inhibitors for solid tumors in the past 20 years (2001-2020). J. Hematol. Oncol. 2020, 13, 1-23. [CrossRef]

17. Cohen, P.; Cross, D.; Jänne, P.A. Kinase drug discovery 20 years after imatinib: Progress and future directions. Nat. Rev. Drug Discov. 2021, 20, 551-569. [CrossRef]

18. O’Brien, S.G.; Guilhot, F.; Larson, R.; Gathmann, I.; Baccarani, M.; Cervantes, F.; Cornelissen, J.J.; Fischer, T.; Hochhaus, A.; Hughes, T.; et al. Imatinib Compared with Interferon and Low-Dose Cytarabine for Newly Diagnosed Chronic-Phase Chronic Myeloid Leukemia. N. Engl. J. Med. 2003, 348, 994-1004. [CrossRef]

19. Parab, T.M.; Derogatis, M.J.; Boaz, A.M.; Grasso, S.A.; Issack, P.S.; Duarte, D.A.; Urayeneza, O.; Vahdat, S.; Qiao, J.-H.; Hinika, G.S. Gastrointestinal stromal tumors: A comprehensive review. J. Gastrointest. Oncol. 2018, 10, 144-154. [CrossRef]

20. Pottier, C.; Fresnais, M.; Gilon, M.; Jérusalem, G.; Longuespée, R.; Sounni, N.E. Tyrosine Kinase Inhibitors in Cancer: Breakthrough and Challenges of Targeted Therapy. Cancers 2020, 12, 731. [CrossRef]

21. Rössler, J.; Geoerger, B.; Taylor, M.; Vassal, G. Small molecule tyrosine kinase inhibitors: Potential role in pediatric malignant solid tumors. Curr. Cancer Drug Targets 2008, 8, 76-85. [CrossRef] [PubMed]

22. Skolnik, J.M.; Adamson, P.C. Tyrosine Kinase Inhibitors in Pediatric Malignancies. Cancer Investig. 2007, 25, 606-612. [CrossRef] [PubMed]

23. Tan, H.-Y.; Wang, N.; Lam, W.; Guo, W.; Feng, Y.; Cheng, Y.-C. Targeting tumour microenvironment by tyrosine kinase inhibitor. Mol. Cancer 2018, 17, 1-15. [CrossRef]

24. Drilon, A.; Laetsch, T.W.; Kummar, S.; Dubois, S.G.; Lassen, U.N.; Demetri, G.D.; Nathenson, M.; Doebele, R.C.; Farago, A.F.; Pappo, A.S.; et al. Efficacy of Larotrectinib in TRKFusion-Positive Cancers in Adults and Children. N. Engl. J. Med. 2018, 378, 731-739. [CrossRef]

25. Hong, D.S.; DuBois, S.G.; Kummar, S.; Farago, A.F.; Albert, C.M.; Rohrberg, K.S.; van Tilburg, C.M.; Nagasubramanian, R.; Berlin, J.D.; Federman, N.; et al. Larotrectinib in patients with TRK fusion-positive solid tumours: A pooled analysis of three phase $1 / 2$ clinical trials. Lancet Oncol. 2020, 21, 531-540. [CrossRef]

26. Mossé, Y.P.; Lim, M.; Voss, S.D.; Wilner, K.; Ruffner, K.; Laliberte, J.; Rolland, D.; Balis, F.M.; Maris, J.M.; Weigel, B.J.; et al. Safety and activity of crizotinib for paediatric patients with refractory solid tumours or anaplastic large-cell lymphoma: A Children's Oncology Group phase 1 consortium study. Lancet Oncol. 2013, 14, 472-480. [CrossRef]

27. Mossé, Y.P.; Voss, S.D.; Lim, M.; Rolland, D.; Minard, C.G.; Fox, E.; Adamson, P.; Wilner, K.; Blaney, S.M.; Weigel, B.J. Targeting ALK with Crizotinib in Pediatric Anaplastic Large Cell Lymphoma and Inflammatory Myofibroblastic Tumor: A Children's Oncology Group Study. J. Clin. Oncol. 2017, 35, 3215-3221. [CrossRef] [PubMed]

28. Christensen, J.G.; Zou, H.Y.; Arango, M.E.; Li, Q.; Lee, J.H.; McDonnell, S.R.; Yamazaki, S.; Alton, G.R.; Mroczkowski, B.; Los, G. Cytoreductive antitumor activity of PF-2341066, a novel inhibitor of anaplastic lymphoma kinase and c-Met, in experimental models of anaplastic large-cell lymphoma. Mol. Cancer Ther. 2007, 6, 3314-3322. [CrossRef] 
29. Zou, H.Y.; Li, Q.; Lee, J.H.; Arango, M.E.; McDonnell, S.R.; Yamazaki, S.; Koudriakova, T.B.; Alton, G.; Cui, J.J.; Kung, P.-P.; et al. An Orally Available Small-Molecule Inhibitor of c-Met, PF-2341066, Exhibits Cytoreductive Antitumor Efficacy through Antiproliferative and Antiangiogenic Mechanisms. Cancer Res. 2007, 67, 4408-4417. [CrossRef]

30. Pacenta, H.L.; E Macy, M. Entrectinib and other ALK/TRK inhibitors for the treatment of neuroblastoma. Drug Des. Dev. Ther. 2018, 12, 3549-3561. [CrossRef]

31. Ardini, E.; Menichincheri, M.; Banfi, P.; Bosotti, R.; De Ponti, C.; Pulci, R.; Ballinari, D.; Ciomei, M.; Texido, G.; Degrassi, A.; et al. Entrectinib, a Pan-TRK, ROS1, and ALK Inhibitor with Activity in Multiple Molecularly Defined Cancer Indications. Mol. Cancer Ther. 2016, 15, 628-639. [CrossRef]

32. Doebele, R.C.; Drilon, A.; Paz-Ares, L.; Siena, S.; Shaw, A.T.; Farago, A.F.; Blakely, C.M.; Seto, T.; Cho, B.C.; Tosi, D.; et al. Entrectinib in patients with advanced or metastatic NTRK fusion-positive solid tumours: Integrated analysis of three phase 1-2 trials. Lancet Oncol. 2020, 21, 271-282. [CrossRef]

33. Wirth, L.J.; Sherman, E.; Robinson, B.; Solomon, B.; Kang, H.; Lorch, J.; Worden, F.; Brose, M.; Patel, J.; Leboulleux, S.; et al. Efficacy of Selpercatinib in RET-Altered Thyroid Cancers. N. Engl. J. Med. 2020, 383, 825-835. [CrossRef]

34. Subbiah, V.; Velcheti, V.; Tuch, B.; Ebata, K.; Busaidy, N.; Cabanillas, M.; Wirth, L.; Stock, S.; Smith, S.; Lauriault, V.; et al. Selective RET kinase inhibition for patients with RET-altered cancers. Ann. Oncol. 2018, 29, 1869-1876. [CrossRef]

35. Italiano, A.; Mir, O.; Mathoulin-Pelissier, S.; Penel, N.; Piperno-Neumann, S.; Bompas, E.; Chevreau, C.; Duffaud, F.; Entz-Werlé, N.; Saada, E.; et al. Cabozantinib in patients with advanced Ewing sarcoma or osteosarcoma (CABONE): A multicentre, single-arm, phase 2 trial. Lancet Oncol. 2020, 21, 446-455. [CrossRef]

36. Akshintala, S.; Widemann, B.C.; Barkauskas, D.A.; Hall, D.; Reid, J.M.; Voss, S.D.; Kim, A.; Fox, E.; Weigel, B. Phase 2 trial of cabozantinib in children and young adults with refractory sarcomas, Wilms tumor, and rare tumors: Children's Oncology Group Study (ADVL1622). J. Clin. Oncol. 2021, 39, 10010. [CrossRef]

37. Duffaud, F.; Mir, O.; Boudou-Rouquette, P.; Piperno-Neumann, S.; Penel, N.; Bompas, E.; Delcambre, C.; Kalbacher, E.; Italiano, A.; Collard, O.; et al. Efficacy and safety of regorafenib in adult patients with metastatic osteosarcoma: A non-comparative, randomised, double-blind, placebo-controlled, phase 2 study. Lancet Oncol. 2019, 20, 120-133. [CrossRef]

38. Duffaud, F.; Blay, J.-Y.; Mir, O.; Chevreau, C.; Rouquette, P.B.; Kalbacher, E.; Penel, N.; Perrin, C.; Laurence, V.; Bompas, E.; et al. LBA68 Results of the randomized, placebo (PL)-controlled phase II study evaluating the efficacy and safety of regorafenib (REG) in patients (pts) with metastatic relapsed Ewing sarcoma (ES), on behalf of the French Sarcoma Group (FSG) and UNICANCER. Ann. Oncol. 2020, 31, S1199. [CrossRef]

39. Wilhelm, S.M.; Dumas, J.; Adnane, L.; Lynch, M.; Carter, C.A.; Schütz, G.; Thierauch, K.-H.; Zopf, D. Regorafenib (BAY 73-4506): A new oral multikinase inhibitor of angiogenic, stromal and oncogenic receptor tyrosine kinases with potent preclinical antitumor activity. Int. J. Cancer 2011, 129, 245-255. [CrossRef]

40. Attia, S.; Bolejack, V.; Ganjoo, K.N.; George, S.; Agulnik, M.; Rushing, D.A.; Loggers, E.T.; Livingston, M.B.; Wright, J.A.; Chawla, S.P.; et al. A phase II trial of regorafenib (REGO) in patients (pts) with advanced Ewing sarcoma and related tumors (EWS) of soft tissue and bone: SARC024 trial results. J. Clin. Oncol. 2017, 35, 11005. [CrossRef]

41. Davis, L.E.; Bolejack, V.; Ryan, C.W.; Ganjoo, K.N.; Loggers, E.T.; Chawla, S.; Agulnik, M.; Livingston, M.B.; Reed, D.; Keedy, V.; et al. Randomized Double-Blind Phase II Study of Regorafenib in Patients with Metastatic Osteosarcoma. J. Clin. Oncol. 2019, 37, 1424-1431. [CrossRef] [PubMed]

42. Gaspar, N.; Casanova, M.; Sirvent, F.J.B.; Venkatramani, R.; Morland, B.; Gambart, M.; Thebaud, E.; Strauss, S.J.; Locatelli, F.; Melcon, S.G.; et al. Single-agent expansion cohort of lenvatinib (LEN) and combination dose-finding cohort of LEN + etoposide (ETP) + ifosfamide (IFM) in patients (pts) aged 2 to $\leq 25$ years with relapsed/refractory osteosarcoma (OS). J. Clin. Oncol. 2018, 36, 11527. [CrossRef]

43. Hussein, Z.; Mizuo, H.; Hayato, S.; Namiki, M.; Shumaker, R. Clinical Pharmacokinetic and Pharmacodynamic Profile of Lenvatinib, an Orally Active, Small-Molecule, Multitargeted Tyrosine Kinase Inhibitor. Eur. J. Drug Metab. Pharmacokinet. 2017, 42, 903-914. [CrossRef] [PubMed]

44. Grignani, G.; Palmerini, E.; Dileo, P.; Asaftei, S.D.; D’Ambrosio, L.; Pignochino, Y.; Mercuri, M.; Picci, P.; Fagioli, F.; Casali, P.G.; et al. A phase II trial of sorafenib in relapsed and unresectable high-grade osteosarcoma after failure of standard multimodal therapy: An Italian Sarcoma Group study. Ann. Oncol. 2012, 23, 508-516. [CrossRef]

45. Mao, W.-F.; Shao, M.-H.; Gao, P.-T.; Ma, J.; Li, H.-J.; Li, G.-L.; Han, B.-H.; Yuan, C.-G. The important roles of RET, VEGFR2 and the RAF/MEK/ERK pathway in cancer treatment with sorafenib. Acta Pharmacol. Sin. 2012, 33, 1311-1318. [CrossRef]

46. Tian, Z.; Niu, X.; Yao, W. Receptor Tyrosine Kinases in Osteosarcoma Treatment: Which Is the Key Target? Front. Oncol. 2020, 10, 1642. [CrossRef]

47. Xie, L.; Xu, J.; Sun, X.; Tang, X.; Yan, T.; Yang, R.; Guo, W. Apatinib for Advanced Osteosarcoma after Failure of Standard Multimodal Therapy: An Open Label Phase II Clinical Trial. Oncologist 2019, 24, 542. [CrossRef]

48. Tian, S.; Quan, H.; Xie, C.; Guo, H.; Lü, F.; Xu, Y.; Li, J.; Lou, L. YN968D1 is a novel and selective inhibitor of vascular endothelial growth factor receptor-2 tyrosine kinase with potent activity in vitro and in vivo. Cancer Sci. 2011, 102, 1374-1380. [CrossRef]

49. Harris, P.A.; Boloor, A.; Cheung, M.; Kumar, R.; Crosby, R.M.; Davis-Ward, R.G.; Epperly, A.H.; Hinkle, K.W.; Hunter, I.R.N.; Johnson, J.H.; et al. Discovery of 5-[[4-[(2,3-Dimethyl-2H-indazol-6-yl)methylamino]-2-pyrimidinyl]amino]-2-methylbenzenesulfonamide (Pazopanib), a Novel and Potent Vascular Endothelial Growth Factor Receptor Inhibitor. J. Med. Chem. 2008, 51, 4632-4640. [CrossRef] 
50. Maki, R.G.; D’Adamo, D.R.; Keohan, M.L.; Saulle, M.; Schuetze, S.M.; Undevia, S.D.; Livingston, M.B.; Cooney, M.M.; Hensley, M.L.; Mita, M.M.; et al. Phase II Study of Sorafenib in Patients with Metastatic or Recurrent Sarcomas. J. Clin. Oncol. 2009, 27, 3133-3140. [CrossRef]

51. Weiss, A.R.; Chen, Y.-L.; Scharschmidt, T.J.; Chi, Y.-Y.; Tian, J.; O Black, J.; Davis, J.L.; Fanburg-Smith, J.C.; Zambrano, E.; Anderson, J.; et al. Pathological response in children and adults with large unresected intermediate-grade or high-grade soft tissue sarcoma receiving preoperative chemoradiotherapy with or without pazopanib (ARST1321): A multicentre, randomised, open-label, phase 2 trial. Lancet Oncol. 2020, 21, 1110-1122. [CrossRef]

52. Drilon, A. TRK inhibitors in TRK fusion-positive cancers. Ann. Oncol. 2019, 30, 23-30. [CrossRef]

53. Doebele, R.C.; Davis, L.E.; Vaishnavi, A.; Le, A.T.; Estrada-Bernal, A.; Keysar, S.B.; Jimeno, A.; Varella-Garcia, M.; Aisner, D.L.; Li, Y.; et al. An Oncogenic NTRK Fusion in a Patient with Soft-Tissue Sarcoma with Response to the Tropomyosin-Related Kinase Inhibitor LOXO-101. Cancer Discov. 2015, 5, 1049-1057. [CrossRef]

54. Vaishnavi, A.; Le, A.T.; Doebele, R.C. TRKing Down an Old Oncogene in a New Era of Targeted Therapy. Cancer Discov. 2014, 5, 25-34. [CrossRef]

55. Albert, C.M.; Davis, J.L.; Federman, N.; Casanova, M.; Laetsch, T.W. TRK Fusion Cancers in Children: A Clinical Review and Recommendations for Screening. J. Clin. Oncol. 2019, 37, 513-524. [CrossRef]

56. Davis, J.L.; Rudzinski, E.R. Pediatric and Infantile Fibroblastic/Myofibroblastic Tumors in the Molecular Era. Surg. Pathol. Clin. 2020, 13, 739-762. [CrossRef]

57. Zhao, X.; Kotch, C.; Fox, E.; Surrey, L.F.; Wertheim, G.B.; Baloch, Z.W.; Lin, F.; Pillai, V.; Luo, M.; Kreiger, P.A.; et al. NTRK Fusions Identified in Pediatric Tumors: The Frequency, Fusion Partners, and Clinical Outcome. JCO Precis. Oncol. 2021, 1, 204-214. [CrossRef]

58. Borre, P.V.; Schrock, A.B.; Anderson, P.M.; Morris, J.C.; Heilmann, A.M.; Holmes, O.; Wang, K.; Johnson, A.; Waguespack, S.G.; $\mathrm{Ou}$, S.I.; et al. Pediatric, Adolescent, and Young Adult Thyroid Carcinoma Harbors Frequent and Diverse Targetable Genomic Alterations, Including Kinase Fusions. Oncologist 2017, 22, 255-263. [CrossRef]

59. Wiesner, T.; Kutzner, H.; Cerroni, L.; Mihm, M.C.; Busam, K.J.; Murali, R. Genomic aberrations in spitzoid melanocytic tumours and their implications for diagnosis, prognosis and therapy. Pathology 2016, 48, 113-131. [CrossRef]

60. Dubois, S.G.; Laetsch, T.W.; Federman, N.; Turpin, B.K.; Albert, C.M.; Nagasubramanian, R.; Anderson, M.E.; Davis, J.L.; Qamoos, H.E.; Reynolds, M.E.; et al. The use of neoadjuvant larotrectinib in the management of children with locally advanced TRK fusion sarcomas. Cancer 2018, 124, 4241-4247. [CrossRef]

61. Ameline, B.; Saba, K.; Kovac, M.; Magnusson, L.; Witt, O.; Bielack, S.; Nathrath, M.; Nord, K.H.; Baumhoer, D. NTRK fusions in osteosarcoma are rare and non-functional events. J. Pathol. Clin. Res. 2020, 6, 107-112. [CrossRef] [PubMed]

62. Drilon, A.; Nagasubramanian, R.; Blake, J.F.; Ku, N.; Tuch, B.B.; Ebata, K.; Smith, S.; Lauriault, V.; Kolakowski, G.R.; Brandhuber, B.J.; et al. A Next-Generation TRK Kinase Inhibitor Overcomes Acquired Resistance to Prior TRK Kinase Inhibition in Patients with TRK Fusion-Positive Solid Tumors. Cancer Discov. 2017, 7, 963-972. [CrossRef] [PubMed]

63. Drilon, A.; Ou, S.-H.I.; Cho, B.C.; Kim, D.-W.; Lee, J.; Lin, J.J.; Zhu, V.W.; Ahn, M.-J.; Camidge, D.R.; Nguyen, J.; et al. Repotrectinib (TPX-0005) Is a Next-Generation ROS1/TRK/ALK Inhibitor That Potently Inhibits ROS1/TRK/ALK Solvent- Front Mutations. Cancer Discov. 2018, 8, 1227-1236. [CrossRef] [PubMed]

64. Lawrence, B.; Perez-Atayde, A.; Hibbard, M.K.; Rubin, B.P.; Cin, P.D.; Pinkus, J.L.; Pinkus, G.S.; Xiao, S.; Yi, E.S.; Fletcher, C.D.; et al. TPM3-ALK and TPM4-ALK Oncogenes in Inflammatory Myofibroblastic Tumors. Am. J. Pathol. 2000, 157, 377-384. [CrossRef]

65. Zeng, Y.; Feldman, A.L. Genetics of anaplastic large cell lymphoma. Leuk. Lymphoma 2015, 57, 21-27. [CrossRef]

66. Pugh, T.; Morozova, O.; Attiyeh, E.F.; Asgharzadeh, S.; Wei, J.S.; Auclair, D.; Carter, S.L.; Cibulskis, K.; Hanna, M.; Kiezun, A.; et al. The genetic landscape of high-risk neuroblastoma. Nat. Genet. 2013, 45, 279-284. [CrossRef]

67. Bresler, S.C.; Wood, A.C.; Haglund, E.A.; Courtright, J.; Belcastro, L.T.; Plegaria, J.S.; Cole, K.; Toporovskaya, Y.; Zhao, H.; Carpenter, E.L.; et al. Differential Inhibitor Sensitivity of Anaplastic Lymphoma Kinase Variants Found in Neuroblastoma. Sci. Transl. Med. 2011, 3, 108ra114. [CrossRef]

68. Krytska, K.; Ryles, H.T.; Sano, R.; Raman, P.; Infarinato, N.R.; Hansel, T.D.; Makena, M.R.; Song, M.M.; Reynolds, C.P.; Mossé, Y.P. Crizotinib Synergizes with Chemotherapy in Preclinical Models of Neuroblastoma. Clin. Cancer Res. 2016, 22, 948-960. [CrossRef]

69. Alam, M.W.; Borenäs, M.; Lind, D.E.; Cervantes-Madrid, D.; Umapathy, G.; Palmer, R.H.; Hallberg, B. Alectinib, an Anaplastic Lymphoma Kinase Inhibitor, Abolishes ALK Activity and Growth in ALK-Positive Neuroblastoma Cells. Front. Oncol. 2019, 9 , 579. [CrossRef]

70. Guan, J.; Fransson, S.; Siaw, J.T.; Treis, D.; Eynden, J.V.D.; Chand, D.; Umapathy, G.; Ruuth, K.; Svenberg, P.; Wessman, S.; et al. Clinical response of the novel activating ALK-I1171T mutation in neuroblastoma to the ALK inhibitor ceritinib. Mol. Case Stud. 2018, 4, a002550. [CrossRef]

71. Infarinato, N.R.; Park, J.H.; Krytska, K.; Ryles, H.T.; Sano, R.; Szigety, K.M.; Li, Y.; Zou, H.Y.; Lee, N.V.; Smeal, T.; et al. The ALK/ROS1 Inhibitor PF-06463922 Overcomes Primary Resistance to Crizotinib in ALK-Driven Neuroblastoma. Cancer Discov. 2016, 6, 96-107. [CrossRef]

72. Lovly, C.; Heuckmann, J.M.; De Stanchina, E.; Chen, H.; Thomas, R.K.; Liang, C.; Pao, W. Insights into ALK-Driven Cancers Revealed through Development of Novel ALK Tyrosine Kinase Inhibitors. Cancer Res. 2011, 71, 4920-4931. [CrossRef] 
73. Goldsmith, K.C.; Kayser, K.; Groshen, S.G.; Chioda, M.; Thurm, H.C.; Chen, J.; Peltz, G.; Granger, M.; Maris, J.; Matthay, K.K.; et al. Phase I trial of lorlatinib in patients with ALK-driven refractory or relapsed neuroblastoma: A New Approaches to Neuroblastoma Consortium study. J. Clin. Oncol. 2020, 38, 10504. [CrossRef]

74. Heath, J.A.; Campbell, M.A.; Thomas, A.; Solomon, B. Good clinical response to alectinib, a second generation ALK inhibitor, in refractory neuroblastoma. Pediatr. Blood Cancer 2018, 65, e27055. [CrossRef]

75. Schulte, J.H.; Moreno, L.; Ziegler, D.S.; Marshall, L.V.; Zwaan, C.M.; Irwin, M.; Casanova, M.; Sabado, C.; Wulff, B.; Stegert, M.; et al. Final analysis of phase I study of ceritinib in pediatric patients with malignancies harboring activated anaplastic lymphoma kinase (ALK). J. Clin. Oncol. 2020, 38, 10505. [CrossRef]

76. Nakagawara, A.; Azar, C.G.; Scavarda, N.J.; Brodeur, G.M. Expression and function of TRK-B and BDNF in human neuroblastomas. Mol. Cell. Biol. 1994, 14, 759-767. [CrossRef]

77. Marcus, L.; Donoghue, M.; Aungst, S.; Myers, C.E.; Helms, W.S.; Shen, G.; Zhao, H.; Stephens, O.; Keegan, P.; Pazdur, R. FDA Approval Summary: Entrectinib for the Treatment of NTRK gene Fusion Solid Tumors. Clin. Cancer Res. 2021, 27, 928-932. [CrossRef]

78. Iyer, R.; Wehrmann, L.; Golden, R.L.; Naraparaju, K.; Croucher, J.L.; MacFarland, S.P.; Guan, P.; Kolla, V.; Wei, G.; Cam, N.; et al. Entrectinib is a potent inhibitor of Trk-driven neuroblastomas in a xenograft mouse model. Cancer Lett. 2016, 372, 179-186. [CrossRef]

79. Mostoufi-Moab, S.; Labourier, E.; Sullivan, L.; Livolsi, V.; Li, Y.; Xiao, R.; Beaudenon-Huibregtse, S.; Kazahaya, K.; Adzick, N.S.; Baloch, Z.; et al. Molecular Testing for Oncogenic Gene Alterations in Pediatric Thyroid Lesions. Thyroid 2018, 28, 60-67. [CrossRef]

80. Mulligan, L.M. RET revisited: Expanding the oncogenic portfolio. Nat. Rev. Cancer 2014, 14, 173-186. [CrossRef]

81. Elisei, R.; Schlumberger, M.J.; Müller, S.P.; Schöffski, P.; Brose, M.S.; Shah, M.H.; Licitra, L.; Jarząb, B.; Medvedev, V.; Kreissl, M.C.; et al. Cabozantinib in Progressive Medullary Thyroid Cancer. J. Clin. Oncol. 2013, 31, 3639-3646. [CrossRef] [PubMed]

82. Wells, S.A., Jr.; Robinson, B.G.; Gagel, R.F.; Dralle, H.; Fagin, J.A.; Santoro, M.; Baudin, E.; Elisei, R.; Jarzab, B.; Vasselli, J.R.; et al. Vandetanib in Patients with Locally Advanced or Metastatic Medullary Thyroid Cancer: A Randomized, Double-Blind Phase III Trial. J. Clin. Oncol. 2012, 30, 134-141. [CrossRef] [PubMed]

83. Porta, R.; Borea, R.; Coelho, A.; Khan, S.; Araújo, A.; Reclusa, P.; Franchina, T.; Van Der Steen, N.; Van Dam, P.; Ferri, J.; et al. FGFR a promising druggable target in cancer: Molecular biology and new drugs. Crit. Rev. Oncol. 2017, 113, 256-267. [CrossRef] [PubMed]

84. Vi, J.G.T.; Cheuk, A.T.; Tsang, P.S.; Chung, J.-Y.; Song, Y.K.; Desai, K.; Yu, Y.; Chen, Q.-R.; Shah, K.; Youngblood, V.; et al. Identification of FGFR4-activating mutations in human rhabdomyosarcomas that promote metastasis in xenotransplanted models. J. Clin. Investig. 2009, 119, 3395-3407. [CrossRef] [PubMed]

85. Perera, T.P.; Jovcheva, E.; Mevellec, L.; Vialard, J.; De Lange, D.; Verhulst, T.; Paulussen, C.; Van De Ven, K.; King, P.; Freyne, E.; et al. Discovery and Pharmacological Characterization of JNJ-42756493 (Erdafitinib), a Functionally Selective Small-Molecule FGFR Family Inhibitor. Mol. Cancer Ther. 2017, 16, 1010-1020. [CrossRef]

86. Shibuya, M. Vascular Endothelial Growth Factor (VEGF) and Its Receptor (VEGFR) Signaling in Angiogenesis: A Crucial Target for Anti- and Pro-Angiogenic Therapies. Genes Cancer 2011, 2, 1097-1105. [CrossRef]

87. Hamberg, P.; Verweij, J.; Sleijfer, S. (Pre-)Clinical Pharmacology and Activity of Pazopanib, a Novel Multikinase Angiogenesis Inhibitor. Oncologist 2010, 15, 539-547. [CrossRef]

88. Lee, A.T.J.; Jones, R.L.; Huang, P.H. Pazopanib in advanced soft tissue sarcomas. Signal Transduct. Target. Ther. 2019, 4, 1-10. [CrossRef]

89. Van der Graaf, W.T.; Blay, J.-Y.; Chawla, S.P.; Kim, D.-W.; Bui-Nguyen, B.; Casali, P.G.; Schöffski, P.; Aglietta, M.; Staddon, A.P.; Beppu, Y.; et al. Pazopanib for metastatic soft-tissue sarcoma (PALETTE): A randomised, double-blind, placebo-controlled phase 3 trial. Lancet 2012, 379, 1879-1886. [CrossRef]

90. Dubois, S.G.; Marina, N.; Bender, J.G. Angiogenesis and vascular targeting in Ewing sarcoma. Cancer 2009, 116, 749-757. [CrossRef]

91. Li, Y.-S.; Liu, Q.; Tian, J.; He, H.-B.; Luo, W. Angiogenesis Process in Osteosarcoma: An Updated Perspective of Pathophysiology and Therapeutics. Am. J. Med. Sci. 2019, 357, 280-288. [CrossRef]

92. Just, M.A.; Van Mater, D.; Wagner, L.M. Receptor tyrosine kinase inhibitors for the treatment of osteosarcoma and Ewing sarcoma. Pediatr. Blood Cancer 2021, 68, e29084. [CrossRef]

93. Xie, L.; Xu, J.; Sun, X.; Tang, X.; Yan, T.; Yang, R.; Guo, W. Anorexia, Hypertension, Pneumothorax, and Hypothyroidism: Potential Signs of Improved Clinical Outcome Following Apatinib in Advanced Osteosarcoma. Cancer Manag. Res. 2020, 12, 91-102. [CrossRef]

94. Bond, M.; Bernstein, M.L.; Pappo, A.; Schultz, K.; Krailo, M.; Blaney, S.M.; Adamson, P.C. A phase II study of imatinib mesylate in children with refractory or relapsed solid tumors: A Children's Oncology Group study. Pediatr. Blood Cancer 2008, 50, 254-258. [CrossRef]

95. Morandi, F.; Amoroso, L.; Dondero, A.; Castriconi, R.; Parodi, S.; Luksch, R.; Casale, F.; Castellano, A.; Garaventa, A.; Moretta, A.; et al. Updated clinical and biological information from the two-stage phase II study of imatinib mesylate in subjects with relapsed/refractory neuroblastoma. OncoImmunology 2018, 7, e1468953-10. [CrossRef] 
96. Anderson, B.; Jasty-Rao, R.; Wu, Y.-M.; Paul, T.; Robinson, D.; Mody, R.J. Exceptional Response to Cabozantinib in a Patient with Multiply Relapsed Wilms Tumor. JCO Precis. Oncol. 2018, 2, 1-5. [CrossRef]

97. Kim, A.; Widemann, B.C.; Krailo, M.; Ms, N.J.; Fox, E.; Weigel, B.; Blaney, S.M. Phase 2 trial of sorafenib in children and young adults with refractory solid tumors: A report from the Children's Oncology Group. Pediatr. Blood Cancer 2015, 62, 1562-1566. [CrossRef]

98. Pearson, H.; Marshall, L.V.; Carceller, F. Sorafenib in pediatric hepatocellular carcinoma from a clinician perspective. Pediatr. Hematol. Oncol. 2020, 37, 412-423. [CrossRef]

99. Shanmugam, N.; Valamparampil, J.J.; Scott, J.X.; Vij, M.; Narasimhan, G.; Reddy, M.S.; Rela, M. Complete remission of refractory hepatoblastoma after liver transplantation in a child with sorafenib monotherapy: A new hope? Pediatr. Blood Cancer 2017, 64, e26701. [CrossRef]

100. Galvez-Carvajal, L.; Sanchez-Muñoz, A.; Ribelles, N.; Saez, M.; Baena, J.; Ruiz, S.; Ithurbisquy, C.; Alba, E. Targeted treatment approaches in refractory germ cell tumors. Crit. Rev. Oncol. 2019, 143, 130-138. [CrossRef]

101. Gounder, M.M.; Mahoney, M.R.; Van Tine, B.A.; Ravi, V.; Attia, S.; Deshpande, H.A.; Gupta, A.A.; Milhem, M.; Conry, R.M.; Movva, S.; et al. Sorafenib for Advanced and Refractory Desmoid Tumors. N. Engl. J. Med. 2018, 379, 2417-2428. [CrossRef]

102. Agresta, L.; Kim, H.; Turpin, B.K.; Nagarajan, R.; Plemmons, A.; Szabó, S.; Dasgupta, R.; Sorger, J.I.; Pressey, J.G. Pazopanib therapy for desmoid tumors in adolescent and young adult patients. Pediatr. Blood Cancer 2018, 65, e26968. [CrossRef]

103. Robles, J.; Keskinyan, V.S.; Thompson, M.; Davis, J.T.; Van Mater, D. Combination therapy with sorafenib and celecoxib for pediatric patients with desmoid tumor. Pediatr. Hematol. Oncol. 2020, 37, 445-449. [CrossRef] [PubMed]

104. Bender, J.L.G.; Adamson, P.C.; Reid, J.M.; Xu, L.; Baruchel, S.; Shaked, Y.; Kerbel, R.S.; Cooney-Qualter, E.M.; Stempak, D.; Chen, H.X.; et al. Phase I Trial and Pharmacokinetic Study of Bevacizumab in Pediatric Patients with Refractory Solid Tumors: A Children's Oncology Group Study. J. Clin. Oncol. 2008, 26, 399-405. [CrossRef] [PubMed]

105. Chisholm, J.C.; Merks, J.H.; Casanova, M.; Bisogno, G.; Orbach, D.; Gentet, J.-C.; Defachelles, A.-S.; Chastagner, P.; Lowis, S.; Ronghe, M.; et al. Open-label, multicentre, randomised, phase II study of the EpSSG and the ITCC evaluating the addition of bevacizumab to chemotherapy in childhood and adolescent patients with metastatic soft tissue sarcoma (the BERNIE study). Eur. J. Cancer 2017, 83, 177-184. [CrossRef] [PubMed]

106. Navid, F.; Santana, V.M.; Neel, M.; McCarville, M.B.; Shulkin, B.L.; Wu, J.; Billups, C.A.; Mao, S.; Daryani, V.M.; Stewart, C.F.; et al. A phase II trial evaluating the feasibility of adding bevacizumab to standard osteosarcoma therapy. Int. J. Cancer 2017, 141, 1469-1477. [CrossRef] [PubMed]

107. Fukumura, D.; Jain, R.K. Tumor microvasculature and microenvironment: Targets for anti-angiogenesis and normalization. Microvasc. Res. 2007, 74, 72-84. [CrossRef]

108. Yang, J.; Yan, J.; Liu, B. Targeting VEGF/VEGFR to Modulate Antitumor Immunity. Front. Immunol. 2018, 9, 978. [CrossRef]

109. Wilky, B.A.; Trucco, M.M.; Subhawong, T.K.; Florou, V.; Park, W.; Kwon, D.; Wieder, E.D.; Kolonias, D.; Rosenberg, A.E.; Kerr, D.A.; et al. Axitinib plus pembrolizumab in patients with advanced sarcomas including alveolar soft-part sarcoma: A single-centre, single-arm, phase 2 trial. Lancet Oncol. 2019, 20, 837-848. [CrossRef]

110. Palmerini, E.; Lopez-Pousa, A.; Grignani, G.; Redondo, A.; Hindi, N.; Stacchiotti, S.; Sebio, A.; Lopez-Martin, J.A.; Morales, C.M.V.; Martinez-Trufero, J.; et al. IMMUNOSARC: A collaborative Spanish (GEIS) and Italian (ISG) sarcoma groups phase I/II trial of sunitinib and nivolumab in advanced soft tissue and bone sarcoma: Results from the phase II part, bone sarcoma cohort. J. Clin. Oncol. 2020, 38, 11522. [CrossRef]

111. Spigel, D.R.; Reynolds, C.; Waterhouse, D.; Garon, E.B.; Chandler, J.; Babu, S.; Thurmes, P.; Spira, A.; Jotte, R.; Zhu, J.; et al. Phase $1 / 2$ Study of the Safety and Tolerability of Nivolumab Plus Crizotinib for the First-Line Treatment of Anaplastic Lymphoma Kinase Translocation-Positive Advanced Non-Small Cell Lung Cancer (CheckMate 370). J. Thorac. Oncol. 2018, 13, 682-688. [CrossRef]

112. Fleuren, E.D.; Versleijen-Jonkers, Y.; Boerman, O.C.; van der Graaf, W.T. Targeting receptor tyrosine kinases in osteosarcoma and Ewing sarcoma: Current hurdles and future perspectives. Biochim. Biophys. Acta (BBA) Bioenergy 2014, 1845, 266-276. [CrossRef]

113. Pignochino, Y.; Dell'Aglio, C.; Basirico', M.; Capozzi, F.; Soster, M.; Marchio', S.; Bruno, S.; Gammaitoni, L.; Sangiolo, D.; Torchiaro, E.; et al. The Combination of Sorafenib and Everolimus Abrogates mTORC1 and mTORC2 Upregulation in Osteosarcoma Preclinical Models. Clin. Cancer Res. 2013, 19, 2117-2131. [CrossRef]

114. Grignani, G.; Palmerini, E.; Ferraresi, V.; D’Ambrosio, L.; Bertulli, R.M.; Asaftei, S.D.; Tamburini, A.; Pignochino, Y.; Sangiolo, D.; Marchesi, E.; et al. Sorafenib and everolimus for patients with unresectable high-grade osteosarcoma progressing after standard treatment: A non-randomised phase 2 clinical trial. Lancet Oncol. 2015, 16, 98-107. [CrossRef]

115. Wood, A.C.; Krytska, K.; Ryles, H.T.; Infarinato, N.R.; Sano, R.; Hansel, T.D.; Hart, L.S.; King, F.J.; Smith, T.R.; Ainscow, E.; et al. Dual ALK and CDK4/6 Inhibition Demonstrates Synergy against Neuroblastoma. Clin. Cancer Res. 2017, 23, $2856-2868$. [CrossRef]

116. Watts, E.; Heidenreich, D.; Tucker, E.; Raab, M.; Strebhardt, K.; Chesler, L.; Knapp, S.; Bellenie, B.; Hoelder, S. Designing Dual Inhibitors of Anaplastic Lymphoma Kinase (ALK) and Bromodomain-4 (BRD4) by Tuning Kinase Selectivity. J. Med. Chem. 2019, 62, 2618-2637. [CrossRef]

117. Kurmasheva, R.T.; Dudkin, L.; Billups, C.A.; Debelenko, L.V.; Morton, C.L.; Houghton, P.J. The Insulin-like Growth Factor-1 Receptor-Targeting Antibody, CP-751,871, Suppresses Tumor-Derived VEGF and Synergizes with Rapamycin in Models of Childhood Sarcoma. Cancer Res. 2009, 69, 7662-7671. [CrossRef] 
118. Wagner, L.M.; Fouladi, M.; Ahmed, A.; Krailo, M.D.; Weigel, B.; DuBois, S.G.; Doyle, L.A.; Chen, H.; Blaney, S.M. Phase II study of cixutumumab in combination with temsirolimus in pediatric patients and young adults with recurrent or refractory sarcoma: A report from the children's oncology group. Pediatr. Blood Cancer 2015, 62, 440-444. [CrossRef]

119. Vo, K.T.; Michlitsch, J.G.; Shah, A.T.; Reid, J.M.; Burhow, S.A.; Graham, E.M.; Hollinger, F.; Zapala, M.A.; Long-Boyle, J.; Kim, M.-O.; et al. Phase I trial of pazopanib in combination with irinotecan and temozolomide (PAZIT) for children and young adults with advanced sarcoma. J. Clin. Oncol. 2020, 38, 10526. [CrossRef]

120. Russo, I.; Di Paolo, V.; Crocoli, A.; Mastronuzzi, A.; Serra, A.; Di Paolo, P.L.; Di Giannatale, A.; Miele, E.; Milano, G.M. A Chart Review on the Feasibility and Safety of the Vincristine Irinotecan Pazopanib (VIPaz) Association in Children and Adolescents with Resistant or Relapsed Sarcomas. Front. Oncol. 2020, 10, 1228. [CrossRef]

121. Casanova, M.; Bautista, F.; Hewson, Q.C.; Makin, G.; Marshall, L.V.; Verschuur, A.; Canete, A.; Corradini, N.; Ploeger, B.; Mueller, U.; et al. Phase I study of regorafenib in combination with vincristine and irinotecan in pediatric patients with recurrent or refractory solid tumors. J. Clin. Oncol. 2020, 38, 10507. [CrossRef]

122. Furman, W.L.; Navid, F.; Daw, N.C.; McCarville, M.B.; McGregor, L.M.; Spunt, S.L.; Rodriguez-Galindo, C.; Panetta, J.; Crews, K.R.; Wu, J.; et al. Tyrosine Kinase Inhibitor Enhances the Bioavailability of Oral Irinotecan in Pediatric Patients With Refractory Solid Tumors. J. Clin. Oncol. 2009, 27, 4599-4604. [CrossRef] [PubMed]

123. Liu, D.; Flory, J.; Lin, A.; Offin, M.; Falcon, C.; Murciano-Goroff, Y.; Rosen, E.; Guo, R.; Basu, E.; Li, B.; et al. Characterization of on-target adverse events caused by TRK inhibitor therapy. Ann. Oncol. 2020, 31, 1207-1215. [CrossRef] [PubMed]

124. Duffaud, F.; Sleijfer, S.; Litière, S.; Ray-Coquard, I.; Le Cesne, A.; Papai, Z.; Judson, I.; Schöffski, P.; Chawla, S.; Dewji, R.; et al. Hypertension (HTN) as a potential biomarker of efficacy in pazopanib-treated patients with advanced non-adipocytic soft tissue sarcoma. A retrospective study based on European Organisation for Research and Treatment of Cancer (EORTC) 62043 and 62072 trials. Eur. J. Cancer 2015, 51, 2615-2623. [CrossRef]

125. Huang, P.-W.; Chou, W.-C.; Shen, W.-C.; Hung, C.-Y.; Huang, K.-G.; Su, Y.-L.; Lu, C.-H.; Liu, C.-T.; Chang, Y.-S.; Liau, C.-T. Hand-foot skin reaction predicts treatment outcome of pazopanib in patients with metastatic soft tissue sarcoma: A multicenter study in the Asian population. Asia-Pac. J. Clin. Oncol. 2018, 14, 353-360. [CrossRef]

126. Vos, M.; Sleijfer, S.; Litière, S.; Touati, N.; Duffaud, F.; Van Der Graaf, W.T.; Gelderblom, H. Association of pazopanib-induced toxicities with outcome of patients with advanced soft tissue sarcoma; a retrospective analysis based on the European Organisation for Research and Treatment of Cancer (EORTC) 62043 and 62072 clinical trials. Acta Oncol. 2019, 58, 872-879. [CrossRef]

127. Longué, M.; Cabarrou, B.; Wallet, J.; Brodowicz, T.; Roché, H.; Boher, J.-M.; Delord, J.; Penel, N.; Filleron, T. The importance of jointly analyzing treatment administration and toxicity associated with targeted therapies: A case study of regorafenib in soft tissue sarcoma patients. Ann. Oncol. 2018, 29, 1588-1593. [CrossRef]

128. Gore, L.; DeGregori, J.; Porter, C.C. Targeting developmental pathways in children with cancer: What price success? Lancet Oncol. 2013, 14, e70-e78. [CrossRef]

129. Corbaux, P.; El-Madani, M.; Tod, M.; Péron, J.; Maillet, D.; Lopez, J.; Freyer, G.; You, B. Clinical efficacy of the optimal biological dose in early-phase trials of anti-cancer targeted therapies. Eur. J. Cancer 2019, 120, 40-46. [CrossRef]

130. Greengard, E.; Mosse, Y.P.; Liu, X.; Minard, C.G.; Reid, J.M.; Voss, S.; Wilner, K.; Fox, E.; Balis, F.; Blaney, S.M.; et al. Safety, tolerability and pharmacokinetics of crizotinib in combination with cytotoxic chemotherapy for pediatric patients with refractory solid tumors or anaplastic large cell lymphoma (ALCL): A Children's Oncology Group phase 1 consortium study (ADVL1212). Cancer Chemother. Pharmacol. 2020, 86, 829-840. [CrossRef]

131. Tabernero, J.; Bahleda, R.; Dienstmann, R.; Infante, J.R.; Mita, A.; Italiano, A.; Calvo, E.; Moreno, V.; Adamo, B.; Gazzah, A.; et al. Phase I Dose-Escalation Study of JNJ-42756493, an Oral Pan-Fibroblast Growth Factor Receptor Inhibitor, in Patients With Advanced Solid Tumors. J. Clin. Oncol. 2015, 33, 3401-3408. [CrossRef]

132. Loriot, Y.; Necchi, A.; Park, S.H.; Garcia-Donas, J.; Huddart, R.; Burgess, E.; Fleming, M.; Rezazadeh, A.; Mellado, B.; Varlamov, S.; et al. Erdafitinib in Locally Advanced or Metastatic Urothelial Carcinoma. N. Engl. J. Med. 2019, 381, 338-348. [CrossRef]

133. Cardoso, E.; Guidi, M.; Blanchet, B.; Schneider, M.P.; Decosterd, L.; Buclin, T.; Csajka, C.; Widmer, N. Therapeutic Drug Monitoring of Targeted Anticancer Protein Kinase Inhibitors in Routine Clinical Use: A Critical Review. Ther. Drug Monit. 2020, 42, 33-44. [CrossRef]

134. Mir, O.; Touati, N.; Lia, M.; Litière, S.; Le Cesne, A.; Sleijfer, S.; Blay, J.-Y.; Leahy, M.; Young, R.; Mathijssen, R.H.; et al. Impact of Concomitant Administration of Gastric Acid-Suppressive Agents and Pazopanib on Outcomes in Soft-Tissue Sarcoma Patients Treated within the EORTC 62043/62072 Trials. Clin. Cancer Res. 2019, 25, 1479-1485. [CrossRef]

135. Van Leeuwen, R.W.F.; Jansman, F.G.A.; Hunfeld, N.G.; Peric, R.; Reyners, A.K.L.; Imholz, A.L.T.; Brouwers, J.R.B.J.; Aerts, J.G.; Van Gelder, T.; Mathijssen, R.H.J. Tyrosine Kinase Inhibitors and Proton Pump Inhibitors: An Evaluation of Treatment Options. Clin. Pharmacokinet. 2017, 56, 683-688. [CrossRef]

136. Bender, J.L.G.; Lee, A.; Reid, J.M.; Baruchel, S.; Roberts, T.; Voss, S.D.; Wu, B.; Ahern, C.H.; Ingle, A.M.; Harris, P.; et al. Phase I Pharmacokinetic and Pharmacodynamic Study of Pazopanib in Children with Soft Tissue Sarcoma and Other Refractory Solid Tumors: A Children's Oncology Group Phase I Consortium Report. J. Clin. Oncol. 2013, 31, 3034-3043. [CrossRef]

137. Suttle, A.B.; A Ball, H.; Molimard, M.; Hutson, T.; Carpenter, C.M.; Rajagopalan, D.; Lin, Y.; Swann, S.L.; Amado, R.G.; Pandite, L. Relationships between pazopanib exposure and clinical safety and efficacy in patients with advanced renal cell carcinoma. Br. $J$. Cancer 2014, 111, 1909-1916. [CrossRef] 
138. Kasper, B.; Sleijfer, S.; Litière, S.; Marreaud, S.; Verweij, J.; Hodge, R.A.; Bauer, S.; Kerst, J.M.; van der Graaf, W.T.A. Long-term responders and survivors on pazopanib for advanced soft tissue sarcomas: Subanalysis of two European Organisation for Research and Treatment of Cancer (EORTC) clinical trials 62043 and 62072. Ann. Oncol. 2014, 25, 719-724. [CrossRef]

139. Abe, K.; Yamamoto, N.; Hayashi, K.; Takeuchi, A.; Miwa, S.; Inatani, H.; Higuchi, T.; Taniguchi, Y.; Tsuchiya, H. Balancing Prolonged Survival with QoL Using Low-dose Pazopanib Maintenance: A Comparison with the PALETTE Study. Anticancer Res. 2016, 36, 2893-2897.

140. Harris, M.H.; Dubois, S.G.; Bender, J.L.G.; Kimberly, S.; Crompton, B.D.; Parker, E.; Dumont, I.P.; Hong, A.; Guo, D.; Church, A.; et al. Multicenter Feasibility Study of Tumor Molecular Profiling to Inform Therapeutic Decisions in Advanced Pediatric Solid Tumors. JAMA Oncol. 2016, 2, 608-615. [CrossRef]

141. Mody, R.J.; Wu, Y.-M.; Lonigro, R.J.; Cao, X.; Roychowdhury, S.; Vats, P.; Frank, K.M.; Prensner, J.; Asangani, I.; Palanisamy, N.; et al. Integrative Clinical Sequencing in the Management of Refractory or Relapsed Cancer in Youth. JAMA 2015, 314, 913-925. [CrossRef] [PubMed]

142. Worst, B.C.; van Tilburg, C.M.; Balasubramanian, G.P.; Fiesel, P.; Witt, R.; Freitag, A.; Boudalil, M.; Previti, C.; Wolf, S.; Schmidt, S.; et al. Next-generation personalised medicine for high-risk paediatric cancer patients-The INFORM pilot study. Eur. J. Cancer 2016, 65, 91-101. [CrossRef] [PubMed]

143. Neradil, J.; Kyr, M.; Polaskova, K.; Kren, L.; Macigova, P.; Skoda, J.; Sterba, J.; Veselska, R. Phospho-Protein Arrays as Effective Tools for Screening Possible Targets for Kinase Inhibitors and Their Use in Precision Pediatric Oncology. Front. Oncol. 2019, 9, 930. [CrossRef] [PubMed]

144. Subbiah, V.; Wagner, M.J.; McGuire, M.F.; Sarwari, N.M.; Devarajan, E.; Lewis, V.O.; Westin, S.; Kato, S.; Brown, R.E.; Anderson, P. Personalized comprehensive molecular profiling of high risk osteosarcoma: Implications and limitations for precision medicine. Oncotarget 2015, 6, 40642-40654. [CrossRef]

145. Tirtei, E.; Campello, A.; Asaftei, S.; Mareschi, K.; Cereda, M.; Fagioli, F. Precision Medicine in Osteosarcoma: MATCH Trial and Beyond. Cells 2021, 10, 281. [CrossRef]

146. Parsons, D.W.; Janeway, K.A.; Patton, D.R.; Lee, J.; Coffey, B.; Williams, P.M.; Roy-Chowdhuri, S.; Tsongalis, G.J.; Routbort, M.; Ramirez, N.C.; et al. Factors impacting enrollment on NCI-COG Pediatric MATCH trial treatment protocols. J. Clin. Oncol. 2021, 39, 10007. [CrossRef]

147. Van Tilburg, C.M.; Pfaff, E.; Pajtler, K.W.; Langenberg, K.P.; Fiesel, P.; Jones, B.C.; Balasubramanian, G.P.; Stark, S.; Johann, P.D.; Blattner-Johnson, M.; et al. The pediatric precision oncology study INFORM: Clinical outcome and benefit for molecular subgroups. J. Clin. Oncol. 2020, 38, LBA10503. [CrossRef]

148. Lagmay, J.P.; Krailo, M.D.; Dang, H.; Kim, A.; Hawkins, D.S.; Beaty, O.; Widemann, B.C.; Zwerdling, T.; Bomgaars, L.; Langevin, A.-M.; et al. Outcome of Patients With Recurrent Osteosarcoma Enrolled in Seven Phase II Trials Through Children's Cancer Group, Pediatric Oncology Group, and Children's Oncology Group: Learning From the Past to Move Forward. J. Clin. Oncol. 2016, 34, 3031-3038. [CrossRef]

149. Collier, A.B.; Krailo, M.; Dang, H.; DuBois, S.; Hawkins, D.S.; Bernstein, M.; Bomgaars, L.; REed, D.; Gorlick, R.; Janeway, K.A. Outcome of patients with relapsed or progressive Ewing sarcoma enrolled on phase 2 clinical trials: A report from the Children's Oncology Group (COG). In Proceedings of the CTOS Annual Meeting, Tokyo, Japan, 16 November 2019.

150. Mody, R.J.; Prensner, J.; Everett, J.; Parsons, D.W.; Chinnaiyan, A.M. Precision medicine in pediatric oncology: Lessons learned and next steps. Pediatr. Blood Cancer 2017, 64, e26288. [CrossRef]

151. Sholler, G.L.S.; Ferguson, W.; Bergendahl, G.; Bond, J.P.; Neville, K.; Eslin, D.; Brown, V.; Roberts, W.; Wada, R.K.; Oesterheld, J.; et al. Maintenance DFMO Increases Survival in High Risk Neuroblastoma. Sci. Rep. 2018, 8, 14445. [CrossRef]

152. Yu, A.L.; Gilman, A.L.; Ozkaynak, M.F.; London, W.B.; Kreissman, S.G.; Chen, H.X.; Smith, M.; Anderson, B.; Villablanca, J.G.; Matthay, K.K.; et al. Anti-GD2 Antibody with GM-CSF, Interleukin-2, and Isotretinoin for Neuroblastoma. N. Engl. J. Med. 2010, 363, 1324-1334. [CrossRef]

153. Moreno, L.; Innovative Therapies for Children with Cancer (ITCC) Consortium; Pearson, A.D.J.; Paoletti, X.; Jimenez, I.; Geoerger, B.; Kearns, P.; Zwaan, C.M.; Doz, F.; Baruchel, A.; et al. Early phase clinical trials of anticancer agents in children and adolescents-An ITCC perspective. Nat. Rev. Clin. Oncol. 2017, 14, 497-507. [CrossRef]

154. Campbell, B.B.; Light, N.; Fabrizio, D.; Zatzman, M.; Fuligni, F.; De Borja, R.; Davidson, S.; Edwards, M.; Elvin, J.A.; Hodel, K.P.; et al. Comprehensive Analysis of Hypermutation in Human Cancer. Cell 2017, 171, 1042-1056.e10. [CrossRef]

155. Trahair, T.; Gifford, A.J.; Fordham, A.; Mayoh, C.; Fadia, M.; Lukeis, R.; Wood, A.C.; Valvi, S.; Walker, R.D.; Blackburn, J.; et al. Crizotinib and Surgery for Long-Term Disease Control in Children and Adolescents With ALK-Positive Inflammatory Myofibroblastic Tumors. JCO Precis. Oncol. 2019, 3, 1-11. [CrossRef]

156. Bellini, A.; Bernard, V.; Leroy, Q.; Frio, T.R.; Pierron, G.; Combaret, V.; Lapouble, E.; Clement, N.; Rubie, H.; Thebaud, E.; et al. Deep Sequencing Reveals Occurrence of Subclonal ALK Mutations in Neuroblastoma at Diagnosis. Clin. Cancer Res. 2015, 21, 4913-4921. [CrossRef]

157. Combaret, V.; Iacono, I.; Bellini, A.; Brejon, S.; Bernard, V.; Marabelle, A.; Coze, C.; Pierron, G.; Lapouble, E.; Schleiermacher, G.; et al. Detection of tumorALKstatus in neuroblastoma patients using peripheral blood. Cancer Med. 2015, 4, 540-550. [CrossRef]

158. Hamilton, G.; Rath, B.; Klameth, L.; Hochmair, M. Receptor tyrosine kinase expression of circulating tumor cells in small cell lung cancer. Oncoscience 2015, 2, 629-634. [CrossRef] 
159. Oberlick, E.M.; Rees, M.G.; Seashore-Ludlow, B.; Vazquez, F.; Nelson, G.M.; Dharia, N.; Weir, B.A.; Tsherniak, A.; Ghandi, M.; Krill-Burger, J.M.; et al. Small-Molecule and CRISPR Screening Converge to Reveal Receptor Tyrosine Kinase Dependencies in Pediatric Rhabdoid Tumors. Cell Rep. 2019, 28, 2331-2344.e8. [CrossRef]

160. Neel, D.V.; Shulman, D.S.; DuBois, S.G. Timing of first-in-child trials of FDA-approved oncology drugs. Eur. J. Cancer 2019, 112, 49-56. [CrossRef]

161. Cardona, A.F.; Arrieta, O.; Ruiz-Patiño, A.; Sotelo, C.; Zamudio-Molano, N.; Zatarain-Barrón, Z.L.; Ricaurte, L.; Raez, L.; Álvarez, M.P.P.; Barrón, F.; et al. Precision medicine and its implementation in patients with NTRK fusion genes: Perspective from developing countries. Ther. Adv. Respir. Dis. 2020, 14, 1753466620938553. [CrossRef]

162. Shulman, D.S.; Dubois, S.G. Winning the RACE: Expanding pediatric cancer drug approvals. Pediatr. Blood Cancer 2019, 66, e27705. [CrossRef]

163. Groussin, L.; Clerc, J.; Huillard, O. Larotrectinib-Enhanced Radioactive Iodine Uptake in Advanced Thyroid Cancer. N. Engl. J. Med. 2020, 383, 1686-1687. [CrossRef]

164. Becker, A.; Crombag, L.; Heideman, D.; Thunnissen, F.; Van Wijk, A.; Postmus, P.; Smit, E. Retreatment with erlotinib: Regain of TKI sensitivity following a drug holiday for patients with NSCLC who initially responded to EGFR-TKI treatment. Eur. J. Cancer 2011, 47, 2603-2606. [CrossRef] 